\title{
Titanocene(III)-catalyzed conversion of $N$-(epoxyalkyl)anilines into indolines
}

\author{
John P. Maciejewski and Peter Wipf* \\ Department of Chemistry, University of Pittsburgh, Pittsburgh, Pennsylvania 15260, USA \\ E-mail:pwipf@pitt.edu
}

Dedicated to Prof. Heinz Heimgartner on the occasion of his 70th birthday

\begin{abstract}
Densely substituted indolines and azaindolines can be obtained by the titanocene(III) chloride catalyzed reductive opening of $N$-(oxiran-2-ylmethyl)anilines. The reaction optimization, substrate scope, and limitations are discussed, and a mechanistic pathway for the epoxideopening rearrangement is proposed.
\end{abstract}

Keywords: Indoline, titanocene dichloride, $N$-(epoxyalkyl) aniline, radical addition

\section{Introduction}

The indole scaffold is the third most common aromatic building block present in bioactive molecules. ${ }^{1}$ Frequently, indoles are constructed from partially reduced precursors, such as indolines or oxidized derivatives, such as indolinones, and the latter are also often by themselves biologically active. ${ }^{2}$ Furthermore, in the pharmaceutical industry, nitrogen replacements of carbon atoms in the indole scaffold are routinely applied for the investigation of structureactivity relationships (SAR), and indazole and azaindole (pyrrolopyridine) subunits are often found in the molecular structure of therapeutic candidates. ${ }^{3}$ Therefore, both the discovery of new methods as well as the optimization of the scope of well established protocols for the construction of these heterocycles continues to be a focal point of heterocyclic chemistry. We recently developed a synthesis of 3,3-disubstituted indolines that uses in situ generated titanocene(III) chloride ${ }^{4,5}$ to promote a new epoxide-opening rearrangement, transforming $N$ (epoxyalkyl)anilines into indolines. ${ }^{6}$ Although most one-step protocols to prepare indolines through carbon-carbon bond formation involve an activation of an aryl halide using either a transition metal $^{7}$ or a radical initiator, ${ }^{8}$ we envisioned exploring a complementary approach toward indoline preparation that uses the reductive opening of an epoxide derived from an allyl aniline to install a quaternary carbon and the fused pyrrolidine ring in the radical cyclization onto 
the benzene ring. Herein, we now present a full account of the development, substrate scope, and current limitations of this low-valent titanium catalyzed transformation.

\section{Results and Discussion}

The initial methodology development began with studies toward converting epoxide 1a into indoline 2a using $10 \mathrm{~mol} \%$ of in situ generated titanocene(III) chloride in the presence of manganese powder as a stoichiometric reducing agent at room temperature in degassed THF $(0.1$ $\mathrm{M})$. During this process, we detected by GC analysis that in addition to the desired indoline 2a, the hydroquinoline $\mathbf{3 a}$, reduced alcohol $\mathbf{4 a}, \beta$-bond cleavage product $\mathbf{5}$, and deoxygenated product $\mathbf{6}$ were present in the crude reaction mixtures (Scheme 1). The presence of $\mathbf{4 a}, \mathbf{5}$, and $\mathbf{6}$ suggested that the radical cyclization to form the indoline was slower than other competing reaction pathways, thereby causing the mixture of undesired side products.

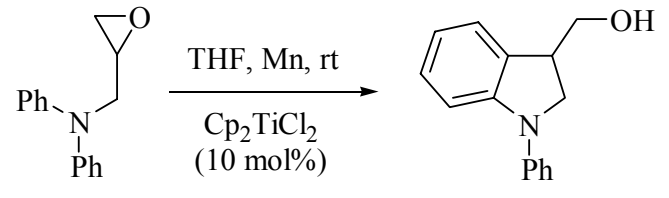

$1 \mathbf{a}$

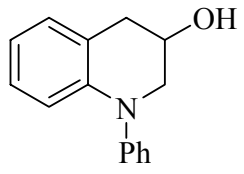

3a

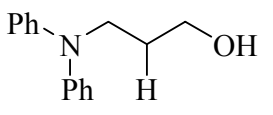

$4 \mathbf{a}$

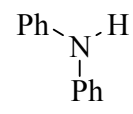

5

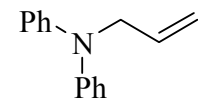

6

Scheme 1. Product distribution for exposure of $N$-(epoxyalkyl)aniline 1a to in situ generated titanocene(III) chloride.

When lowering the reaction concentration to $0.03 \mathrm{M}$ and using $10 \mathrm{~mol} \%$ of precatalyst in the presence of $80 \mathrm{~mol} \%$ of manganese powder under sonication, a 3:1 ratio of indoline $\mathbf{2 a}$ to tetrahydroquinoline 3a was observed by GC analysis of the crude reaction mixture (Table 1, entry 1). Next, we tested if a methyl substituted alkene substrate would react more selectively and avoid the formation of the undesired mixtures of $\mathbf{2 a}$ and 3a. Indeed, when epoxide 1b was treated with in situ generated titanocene (III) chloride, indoline $\mathbf{2 b}$ was obtained in $82 \%$ yield as a single product (entry 2). It was evident that the additional methyl group on the epoxide improved the selectivity in favor of the desired indoline product. We also observed that sonication provided no additional benefits toward promoting the annulation reaction since $\mathbf{2 b}$ was isolated in nearly identical yield when using conventional magnetic stirring (entry 3). To broaden the scope of the methodology, we screened for a suitable replacement for the $N$-phenyl group. When subjecting the secondary amine $\left(\mathrm{R}^{1}=\mathrm{H}\right)$ to the cyclization reaction, only a minor amount of reduced amino alcohol was isolated. The benzyloxycarbonyl (Cbz) group was the preferred choice of protecting group among the candidates screened, which included benzyl, $t$ butyloxycarbonyl, $p$-toluenesulfonyl, and trifluoroacetyl. The Cbz protecting group was optimal since it neither functioned as a radical acceptor nor participated in undesired side reactions with the tethered epoxide during the reaction. 
Subjecting carbamate 1c to catalytic titanocene(III) chloride at room temperature produced a 2:1 mixture of indoline $\mathbf{2 c}$ to alcohol $\mathbf{4 c}$ (Table 1, entry 4). When the precatalyst loading was lowered to $5 \mathrm{~mol} \%$ and then further to $3 \mathrm{~mol} \%$, the product ratio (determined by ${ }^{1} \mathrm{H} \mathrm{NMR}$ analysis of the crude reaction mixtures) of $\mathbf{2 c : 4 c}$ increased from $3: 1$ to $7: 1$, respectively. However, when using $3 \mathrm{~mol} \%$ of the precatalyst, 1c was recovered in $18 \%$ yield. In order to drive the reaction further to completion, the mixture was heated at reflux in THF using $3 \mathrm{~mol} \%$ of the precatalyst. Under these conditions and subsequent hydrogenolysis of the $\mathrm{Cbz}$ group, indoline 7c was isolated in 63\% yield over 2 steps (entry 5). Subjecting the ethoxycarbonylprotected substrate 1d to the optimized conditions afforded the desired indoline in $65 \%$ yield (entry 6). When applied to our model system $\mathbf{1 b}$, these conditions produced indoline $\mathbf{2 b}$ in $89 \%$ yield (entry 7). High yields were also obtained when subjecting epoxide 1a to $3 \mathrm{~mol} \%$ of titanocene dichloride and stoichiometric Mn powder in THF at reflux, affording a 3.8:1 mixture of $\mathbf{2 a}$ and $3 \mathbf{a}$ in $87 \%$ yield (entry 8 ).

Table 1. Conditions screened during the optimization of the epoxide-opening rearrangement
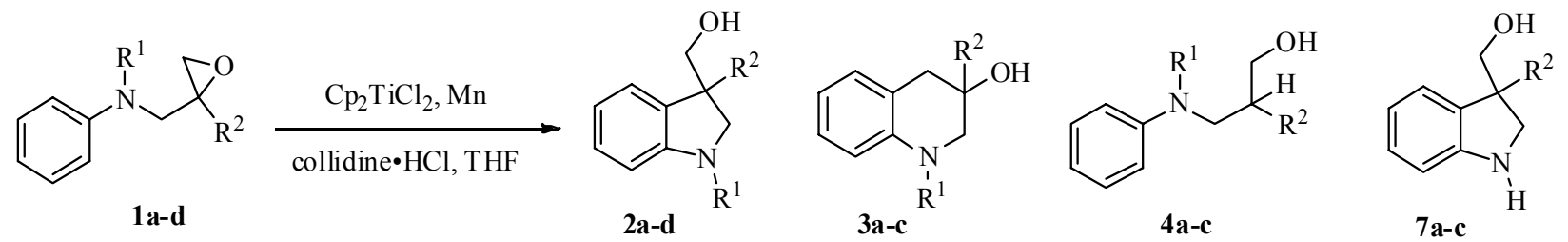

\begin{tabular}{cccccccc}
\hline entry & epoxide ${ }^{\mathrm{a}, \mathrm{b}}$ & $\mathrm{R}^{1}$ & $\mathrm{R}^{2}$ & $\mathrm{Cp}_{2} \mathrm{TiCl}_{2}$ & $\begin{array}{c}\mathrm{Mn} \\
\text { (equiv.) }\end{array}$ & $\begin{array}{c}\text { concentration } \\
{[\mathrm{M}]}\end{array}$ & $\begin{array}{c}\text { product(s), } \\
\text { yield }\end{array}$ \\
\hline 1 & $\mathbf{1 a}$ & $\mathrm{Ph}$ & $\mathrm{H}$ & $10 \mathrm{~mol} \%$ & 0.80 & 0.03 & $\mathbf{2 a : 3 a}(3: 1)^{\mathrm{c}, \mathrm{d}}$ \\
2 & $\mathbf{1 b}$ & $\mathrm{Ph}$ & $\mathrm{CH}_{3}$ & $10 \mathrm{~mol} \%$ & 0.65 & 0.03 & $\mathbf{2 b}, 82 \%^{\mathrm{d}}$ \\
3 & $\mathbf{1 b}$ & $\mathrm{Ph}$ & $\mathrm{CH}_{3}$ & $10 \mathrm{~mol} \%$ & 0.65 & 0.03 & $\mathbf{2 b , 8 4 \%}{ }^{\mathrm{e}}$ \\
4 & $\mathbf{1 c}$ & $\mathrm{Cbz}$ & $\mathrm{CH}_{3}$ & $10 \mathrm{~mol} \%$ & 1.5 & 0.1 & $\mathbf{2 c}: \mathbf{4 c}(2: 1)^{\mathrm{f}}$ \\
5 & $\mathbf{1 c}$ & $\mathrm{Cbz}$ & $\mathrm{CH}_{3}$ & $3 \mathrm{~mol} \%$ & 1.5 & 0.1 & $\mathbf{7 c}, 63 \%^{\mathrm{g}}$ \\
6 & $\mathbf{1 d}$ & $\mathrm{CO}_{2} \mathrm{Et}$ & $\mathrm{CH}_{3}$ & $3 \mathrm{~mol} \%$ & 1.5 & 0.1 & $\mathbf{2 d}, 65 \%$ \\
7 & $\mathbf{1 b}$ & $\mathrm{Ph}$ & $\mathrm{CH}_{3}$ & $3 \mathrm{~mol} \%$ & 1.5 & 0.1 & $\mathbf{2 b}, 89 \%$ \\
8 & $\mathbf{1 a}$ & $\mathrm{Ph}$ & $\mathrm{H}$ & $3 \mathrm{~mol} \%$ & 1.5 & 0.1 & $\mathbf{2 a : 3 a}(3.8: 1)$, \\
& & & & & & & $87 \%$ \\
\hline
\end{tabular}

${ }^{a}$ For epoxide preparation, see experimental section. ${ }^{\mathrm{b}}$ All reactions were performed in degassed THF at reflux unless otherwise noted. ${ }^{c}$ Yield was not determined; product ratio was determined by GC analysis of crude reaction mixtures. ${ }^{\mathrm{d}}$ Reaction was performed in degassed THF at room temperature using sonication. ${ }^{\mathrm{e}}$ Reaction was performed in degassed THF at room temperature using magnetic stirring. ${ }^{\mathrm{f}}$ Reaction was performed at room temperature; yield was not determined; product ratios were obtained by ${ }^{1} \mathrm{H}$ NMR analysis of crude reaction mixtures.

${ }^{\mathrm{g}}$ Yield was determined over 2 steps. 
We also explored the sensitivity of the reaction to both ambient oxygen and water. When subjecting 1c to titanocene(III) catalysis in a reaction flask open to ambient air, we observed only a $14 \%$ yield of $2 \mathrm{c}$ and recovered $43 \%$ of $1 \mathrm{c}$ (Table 2 , entry 1 ). This observation suggested that the desired reaction was inhibited by ambient oxygen. Subjecting 1d to the titanocene(III) catalyzed epoxide opening using a degassed mixture of distilled $\mathrm{THF}: \mathrm{H}_{2} \mathrm{O}$ in an equivolume ratio led to the recovery of $89 \%$ of the starting material (entry 2). Although some titanocene(III) chloride-mediated processes utilize water as a co-solvent, ${ }^{9}$ the desired catalytic process appears to be inhibited by its presence. Additional control experiments using either only $3 \mathrm{~mol} \%$ of the precatalyst (entry 3 ) or only 1.5 equiv. of manganese metal (entry 4) under otherwise identical reaction conditions failed to afford indolines. These results indicated that the in situ generated reagent was responsible for promoting the annulation. In the presence of a catalytic amount of manganese metal, 2c was isolated in $35 \%$ yield, in addition to $38 \%$ of recovered 1c (entry 5).

For further substrate variation, a series of substituted $N$-(epoxyalkyl) anilines were prepared and subjected to titanocene(III) chloride catalysis to afford the respective indolines (Table 3 ). The para- and ortho-methyl substituted substrates 8a and 8b (entries 1 and 2, respectively) afforded indolines in good to modest yields. The 5-methoxyindoline 9c was isolated in low yield ( $21 \%$ yield over 2 steps). In contrast, electron-deficient substrates underwent the epoxideopening rearrangement to afford indolines in good yields (entries 4 and 5).

Table 2. Control experiments to probe reaction limitations

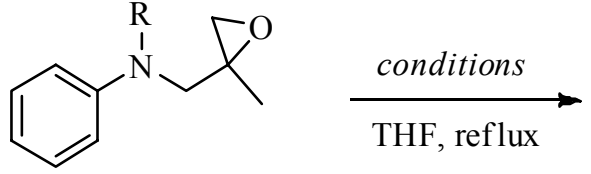

1a-d

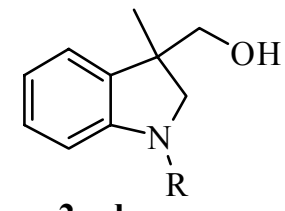

2a-d

\begin{tabular}{cccccc}
\hline entry & epoxide & $\mathrm{R}$ & $\begin{array}{c}\mathrm{Cp}_{2} \mathrm{TiCl}_{2} \\
(\mathrm{~mol} \%)\end{array}$ & $\mathrm{Mn}$ (equiv.) & product(s), yield \\
\hline 1 & $\mathbf{1 c}$ & $\mathrm{Cbz}$ & 3 & 1.5 & $\mathbf{2 c}, 14 \%($ recovered 1c, 43\%) \\
2 & $\mathbf{1 d}$ & $\mathrm{CO}_{2} \mathrm{Et}$ & 3 & 1.5 & $\mathbf{2 d}, 0 \%($ recovered 1d, 89\%) \\
3 & $\mathbf{1 c}$ & $\mathrm{Cbz}$ & 3 & 0 & $\mathbf{2 c}, 0 \%$ \\
4 & $\mathbf{1 c}$ & $\mathrm{Cbz}$ & 0 & 1.5 & $\mathbf{2 c}, 0 \%$ \\
5 & $\mathbf{1 c}$ & $\mathrm{Cbz}$ & 3 & 0.15 & $\mathbf{2 c}, 35 \%($ recovered 1c, $38 \%)$ \\
\hline
\end{tabular}

${ }^{\mathrm{a}}$ Reaction was performed in a flask open to the atmosphere in distilled, non-degassed THF. ${ }^{b}$ Reaction was performed in a degassed mixture of distilled THF: $\mathrm{H}_{2} \mathrm{O}$ (1:1). 
Table 3. Substrates prepared using titanocene(III) chloride catalysis

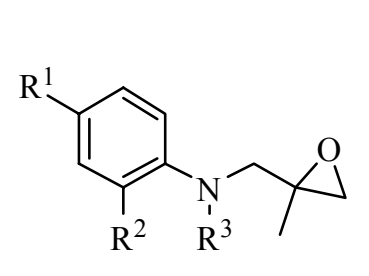

8

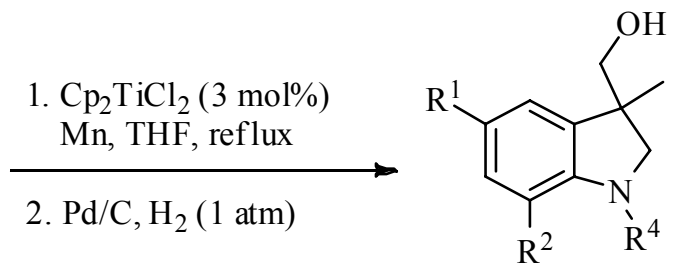

9

\begin{tabular}{cccccccc}
\hline entry & epoxide $^{\mathrm{a}}$ & $\mathrm{R}^{1}$ & $\mathrm{R}^{2}$ & $\mathrm{R}^{3}$ & $\mathrm{R}^{4}$ & product & yield \\
\hline 1 & $\mathbf{8 a}$ & $\mathrm{CH}_{3}$ & $\mathrm{H}$ & $\mathrm{Cbz}$ & $\mathrm{H}$ & $\mathbf{9 a}$ & $62 \%^{\mathrm{b}}$ \\
2 & $\mathbf{8 b}$ & $\mathrm{H}$ & $\mathrm{CH}_{3}$ & $\mathrm{Cbz}$ & $\mathrm{H}$ & $\mathbf{9 b}$ & $35 \%^{\mathrm{b}}$ \\
3 & $\mathbf{8 c}$ & $\mathrm{OCH}_{3}$ & $\mathrm{H}$ & $\mathrm{Cbz}$ & $\mathrm{H}$ & $\mathbf{9 c}$ & $21 \%^{\mathrm{b}}$ \\
4 & $\mathbf{8 d}$ & $\mathrm{CO}_{2} \mathrm{CH}_{3}$ & $\mathrm{H}$ & $\mathrm{Cbz}$ & $\mathrm{H}$ & $\mathbf{9 d}$ & $56 \%^{\mathrm{b}}$ \\
5 & $\mathbf{8 e}$ & $\mathrm{Cl}$ & $\mathrm{H}$ & $\mathrm{Cbz}$ & $\mathrm{Cbz}$ & $\mathbf{9 e}$ & $41 \%^{\mathrm{c}}$ \\
\hline
\end{tabular}

${ }^{\mathrm{a}}$ See experimental section for epoxide preparations. ${ }^{\mathrm{b}}$ Yield was determined over 2 steps. ${ }^{\mathrm{c}} \mathrm{Cbz}$ group was not removed; i.e. step 2 was not performed.

For the study of the regioselectivity of the annulation, epoxide $\mathbf{1 2}$ (prepared in 4 steps from aniline 10) was subjected to the titanocene(III) catalyzed epoxide opening, affording a 1:1 mixture of regioisomers $\mathbf{1 3}$ and $\mathbf{1 4}$ in a combined yield of 63\% (Scheme 2). Subsequent reduction of the ethyl carbamates using lithium aluminum hydride provided $N$-methyl indolines 15 and 16, respectively. 


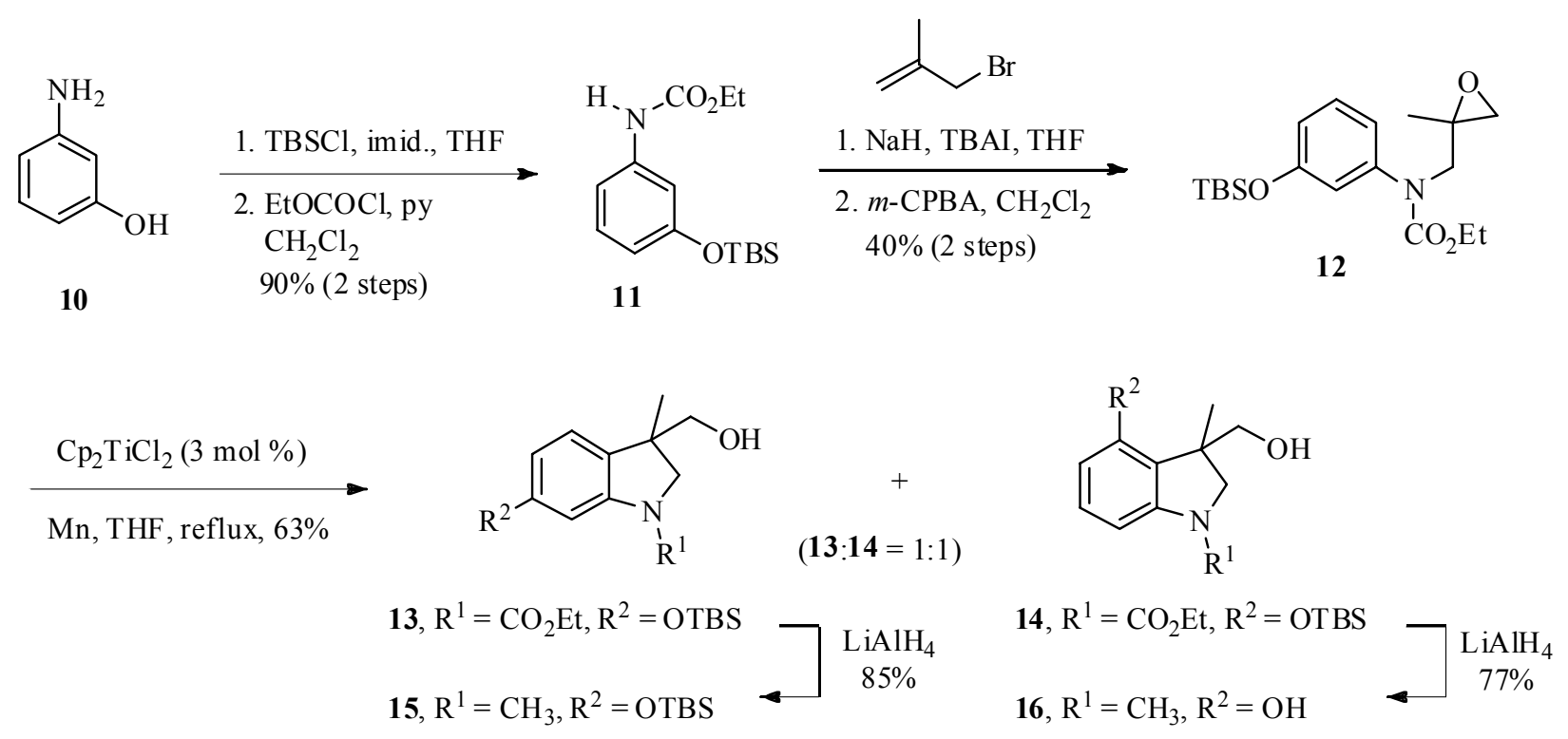

Scheme 2. Regioselectivity of the radical annulation reaction.

We also attempted to prepare heterocycles of higher complexity (Scheme 3). Epoxide 18 was obtained in $61 \%$ yield over 3 steps by alkylation of tetrahydroquinoline 17 with 3-bromo-2methyl propene, followed by $\mathrm{OsO}_{4}$ oxidation and epoxide formation. Subjecting the epoxide to the titanocene(III) catalyzed annulation and protection of the resulting alcohol as the acetate provided 19 in 69\% yield over 2 steps. In contrast, the epoxide 21 (prepared in 4 steps from indole 20) failed to provide the pyrroloindoline 22, possibly due to the ring strain in the fused five-membered ring system. The linearly fused tricyclic hydrocarbazole 25 was obtained, albeit in low yield, from cyclohexene oxide 24. The alcohol function in $\mathbf{2 5}$ was converted to the carbonyl group using Dess-Martin periodinane (DMP) in 63\% yield. The relative configuration of ketone $\mathbf{2 6}$ was assigned to be syn based on the strong nOe between the tertiary methyl group and the methine hydrogen observed in the 2D-NOESY NMR. 


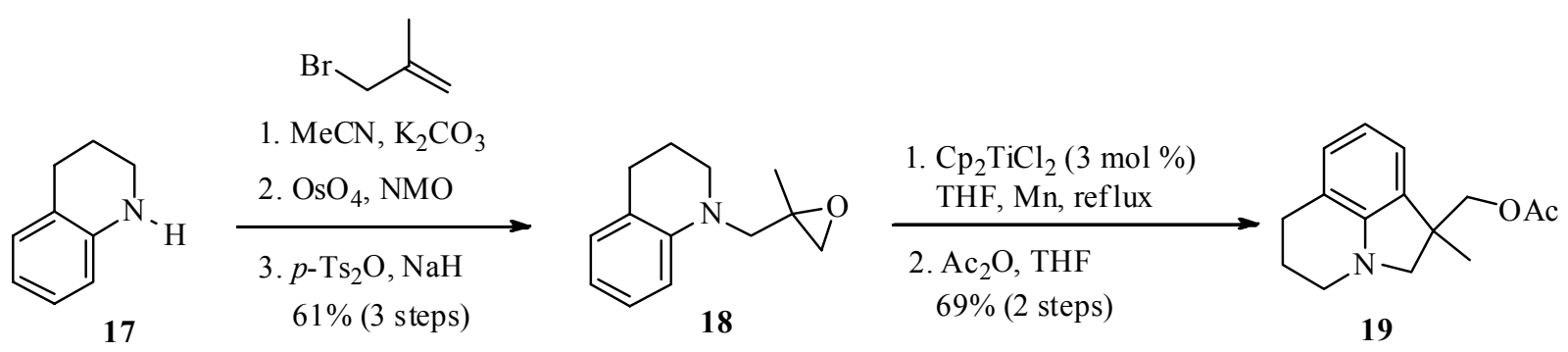

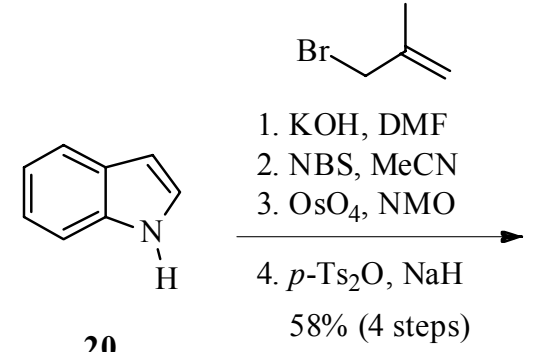

20<smiles>CC1=CCCCC1N(C(=O)OCc1ccccc1)C(=O)c1ccccc1</smiles>

23

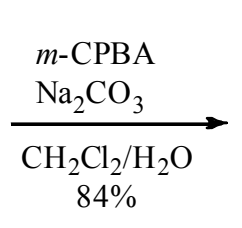

$\mathrm{O}$

2

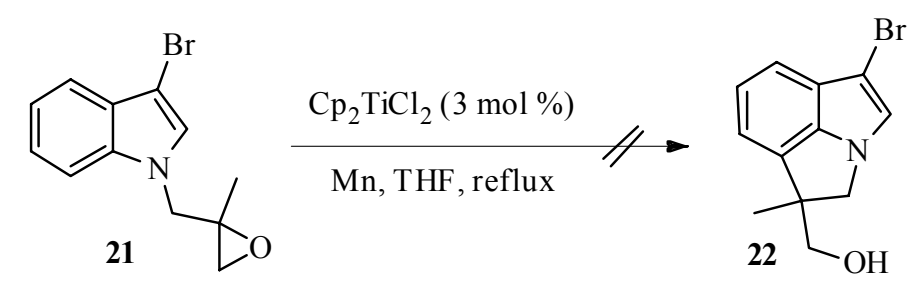

Scheme 3. Conversions of more highly substituted substrates to tricyclic indolines.

As mentioned previously, azaindolines have found broad applications as bioisosteres of indolines in pharmaceutical research. ${ }^{10}$ The use of aminopyridine substrates offered the possibility of applying our methodology toward the preparation of azaindolines. ${ }^{6,11}$ Although the chemoselective epoxidation of alkenes in the presence of the pyridine moiety was precedented, attempts to efficiently prepare the epoxide on an unsubstituted aminopyridine substrate were unsuccessful. This negative result was primarily due to the reactivity of the pyridine nitrogen toward either $m$-CPBA or DMDO, i.e. the formation of $N$-oxides. ${ }^{12}$ In contrast, the orthochlorine substitution ${ }^{13}$ proved to be sufficient to attenuate the reactivity of the pyridine nitrogen lone pair and prevent this undesired oxidation. A Curtius rearrangement of the known carboxylic acid $27^{14}$ followed by subsequent trapping of the intermediate isocyanate with benzyl alcohol afforded the Cbz-protected aminopyridine 28 in 33\% yield over 3 steps (Scheme 4). Subsequent methallylation and epoxidation using $m$-CPBA led to epoxide 29, which, when treated with catalytic titanocene(III) chloride in the presence of stoichiometric manganese powder, provided an intermediate 4,6-dichloro-5-azaindoline. Further conversion of this intermediate with $\mathrm{Pd} / \mathrm{C}$ under an atmosphere of $\mathrm{H}_{2}$ gave azaindoline 30 in 52\% yield over 2 steps. 


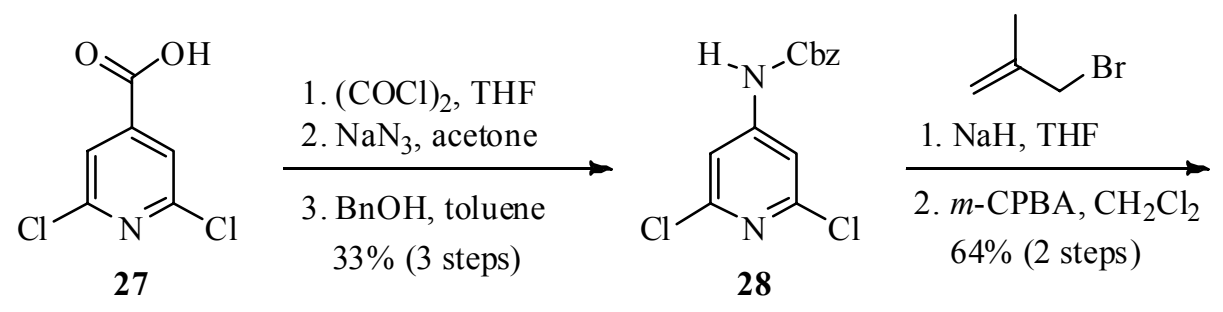<smiles>CC1(CN(C(=O)OCc2ccccc2)c2cc(Cl)nc(Cl)c2)CO1</smiles>

29

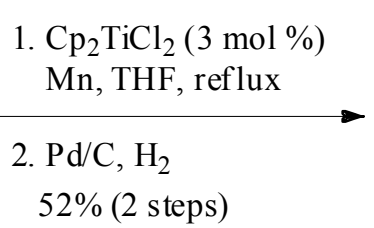

$52 \%$ (2 steps)

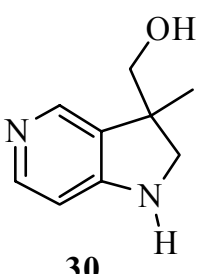

30

Scheme 4. Preparation of 5-azaindoline 30.

Our studies of the mechanism of the titanocene(III)-catalyzed conversion of $\mathrm{N}$ (epoxyalkyl)anilines into indolines and azaindolines are still evolving. Based on our current experimental data, we envision that after the in situ generation of titanocene(III) chloride, the epoxide 31 is reductively opened to form the $\beta$-titanoxy radical 32. This radical may then undergo an addition onto the aromatic ring forming the cyclohexadienyl radical intermediate $\mathbf{3 3}$ (Scheme 5). ${ }^{15}$ Oxidation or disproportionation of the cyclohexadienyl radical followed by proton loss affords indoline 34. ${ }^{16}$ It is unlikely that the oxidation of the cyclohexadienyl radical could be occurring through the precatalyst since using $15 \mathrm{~mol} \%$ of manganese metal in the epoxideopening rearrangement affords only $35 \%$ of the desired indoline (Table 2 , entry 5). To complete the catalytic cycle, protodemetallation by collidinium hydrochloride $(\mathrm{Coll} \bullet \mathrm{HCl})$ leads to product 35, and regenerates the titanocene precatalyst. Alternatively, the titanocene (III) chloride catalyst or the manganese chloride byproducts may serve as Lewis acids to promote an epoxide-opening Friedel-Crafts alkylation. However, 5-membered benzene annulations by epoxide opening under typical Friedel-Crafts conditions are quite inefficient. ${ }^{17}$ Furthermore, it has been shown that the manganese chloride produced in the reaction is incapable of promoting Lewis acid mediated epoxide-opening rearrangements. ${ }^{4 c}$ 


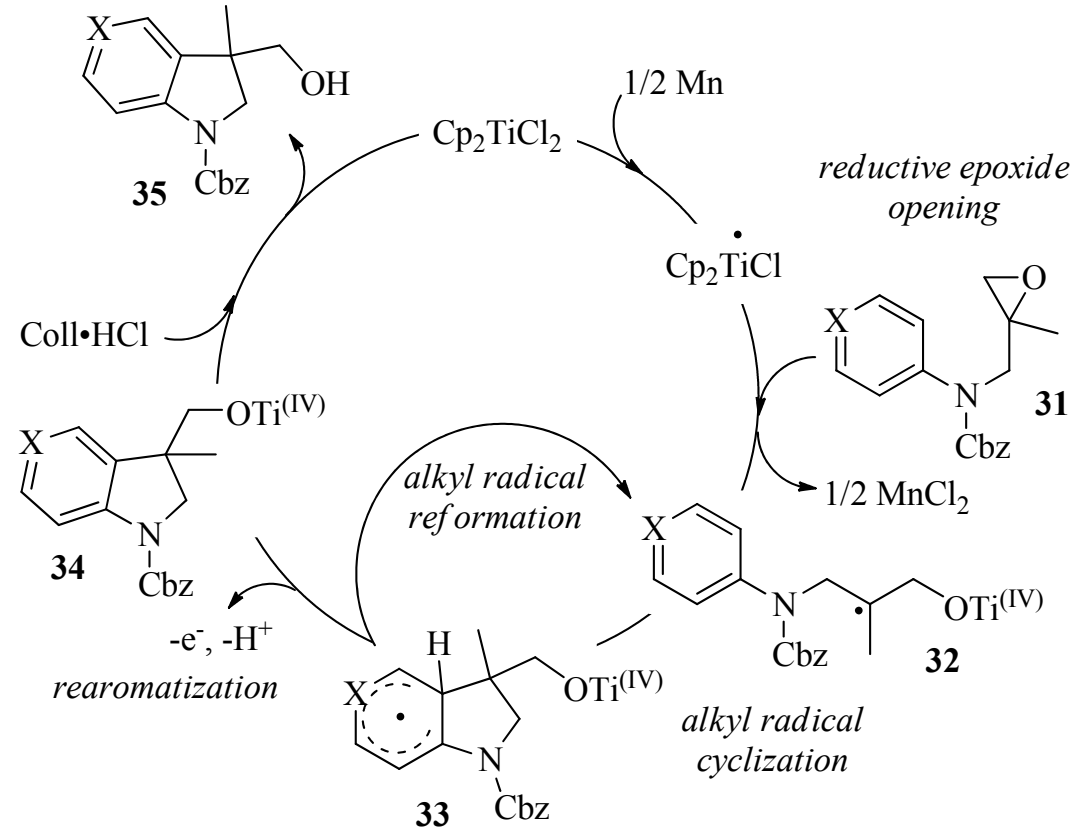

Scheme 5. Proposed catalytic cycle of the epoxide-opening rearrangement process.

\section{Conclusions}

We have developed a new catalytic method to prepare 3,3-disubstituted indolines and azaindolines through an epoxide-opening rearrangement catalyzed by in situ generated titanocene(III) chloride. Although the process does not appear to be regioselective, the target heterocycles can be prepared in good to moderate yields from readily available starting materials and do not require halogenation on the aromatic core. Control experiments indicate that the reaction is sensitive to both water and ambient air and requires the presence of both the precatalyst and a stoichiometric amount of manganese metal to promote the annulation.

\section{Experimental Section}

General. All moisture-sensitive reactions were performed under an atmosphere of dry nitrogen unless otherwise noted. All glassware was dried in an oven at $>140{ }^{\circ} \mathrm{C}$ or flame-dried under an atmosphere of dry nitrogen unless otherwise noted. Diethyl ether was dried by distillation over sodium/benzophenone under an argon atmosphere. Tetrahydrofuran was dried either by distillation over sodium/benzophenone under an argon atmosphere or by distillation over $\mathrm{LiAlH}_{4}$ under a nitrogen atmosphere. Dry $\mathrm{CH}_{2} \mathrm{Cl}_{2}$ and toluene were purified by filtration through an activated alumina column. Unless otherwise stated, solvents and reagents were used as purchased without further purification. Benzyl alcohol was distilled prior to use. Collidine hydrochloride 
was recrystallized from absolute ethanol. Manganese and zinc metals were activated through washing with $1 \mathrm{M} \mathrm{HCl}$, followed by rinsing with acetone and drying under vacuum. Titanocene dichloride was recrystallized from chloroform before use. Analytical thin-layer chromatography (TLC) was preformed on pre-coated silica gel $60 \mathrm{~F}_{254}$ plates (250 $\mu \mathrm{m}$ layer thickness). Visualization was accomplished by using either a $254 \mathrm{~nm}$ UV lamp or by staining with a PMA solution (5 g of phosphomolybdic acid in $100 \mathrm{~mL}$ of $95 \% \mathrm{EtOH}), p$-anisaldehyde solution (2.5 $\mathrm{mL}$ of $p$-anisaldehyde, $2 \mathrm{~mL}$ of $\mathrm{AcOH}$, and $3.5 \mathrm{~mL}$ of conc. $\mathrm{H}_{2} \mathrm{SO}_{4}$ in $100 \mathrm{~mL}$ of $95 \% \mathrm{EtOH}$ ), Vaughn's reagent $\left(4.8 \mathrm{~g}\right.$ of $\left(\mathrm{NH}_{4}\right)_{6} \mathrm{Mo}_{7} \mathrm{O}_{24} \cdot 4 \mathrm{H}_{2} \mathrm{O}$ and $0.2 \mathrm{~g}$ of $\mathrm{Ce}\left(\mathrm{SO}_{4}\right)_{2}$ in $100 \mathrm{~mL}$ of a $3.5 \mathrm{~N}$ $\mathrm{H}_{2} \mathrm{SO}_{4}$ ) or a potassium permanganate solution ( $1.5 \mathrm{~g}$ of $\mathrm{KMnO}_{4}$ and $1.5 \mathrm{~g}$ of $\mathrm{K}_{2} \mathrm{CO}_{3}$ in $100 \mathrm{~mL}$ of a $0.1 \% \mathrm{NaOH}$ solution). NMR spectra were recorded at room temperature in $\mathrm{CDCl}_{3}$ at 300 $\mathrm{MHz} / 75 \mathrm{MHz}\left({ }^{1} \mathrm{H} /{ }^{13} \mathrm{C}\right.$ NMR) using a Bruker Avance $300 \mathrm{MHz}$ spectrometer unless stated otherwise. Chemical shifts $(\delta)$ are reported in parts per million and referenced from the residual solvent peak or tetramethylsilane. Data are reported as follows: chemical shift, multiplicity (app $\mathrm{s}=$ apparent singlet, $\mathrm{s}=$ singlet, $\mathrm{bs}=$ broad singlet, $\mathrm{d}=$ doublet, $\mathrm{bd}=$ broad doublet, $\mathrm{dd}=$ doublet of doublets, $\mathrm{ddd}=$ doublet of doublet of doublets, app $\mathrm{t}=$ apparent triplet, $\mathrm{bt}=$ broad triplet, $\mathrm{t}=$ triplet, $\mathrm{dt}=$ doublet of triplets, $\mathrm{tt}=$ triplet of triplets, $\mathrm{q}=$ quartet, app quint $=$ apparent quintet, $\mathrm{m}$ $=$ multiplet), integration, and coupling constant(s). IR spectra were recorded on either a Nicolet Avatar 360 FT-IR E.S.P. spectrometer ( $\mathrm{KBr}$ or neat) or a Smiths Detection IdentifyIR FT-IR spectrometer (ATR). Melting points were uncorrected and determined using a Laboratory Devices Mel-Temp II. Mass spectrometry data were recorded on a VG-70-70 HF instrument. Titanocene-catalyzed radical cyclization reactions were performed under rigorous exclusion of dioxygen under a positive pressure of dry argon. Tetrahydrofuran, in addition to being distilled, was deoxygenated (freeze-pump-thaw) three times and then stored under a positive pressure of dry argon prior to all titanocene(III) catalyzed annulation reactions. Sonication was accomplished with the Sonics Vibracell device (model VCX 130) equipped with a $2 \mathrm{~mm}$ microtip.

\section{$\boldsymbol{N}$-Allyl- $\boldsymbol{N}$-phenylaniline (6). ${ }^{18}$ General protocol A}

According to a modified literature procedure, ${ }^{18}$ a solution of $5.07 \mathrm{~g}(29.9 \mathrm{mmol})$ of diphenylamine in $45 \mathrm{~mL}$ of acetonitrile was treated with $8.28 \mathrm{~g}(59.9 \mathrm{mmol})$ of $\mathrm{K}_{2} \mathrm{CO}_{3}, 5.2 \mathrm{~mL}$ (59.9 mmol) of allyl bromide, and $533 \mathrm{mg}(1.49 \mathrm{mmol})$ of TBAI. This reaction mixture was heated at reflux and the disappearance of starting material was monitored by TLC (hexanes). The solution was cooled to rt, diluted with $100 \mathrm{~mL}$ of $\mathrm{H}_{2} \mathrm{O}$ and extracted with $3 \mathrm{x} 15 \mathrm{~mL}$ of EtOAc. The combined organic layers were dried $\left(\mathrm{MgSO}_{4}\right)$ and concentrated in vacuo. The residue was purified by chromatography on $\mathrm{SiO}_{2}$ (hexanes) to afford $6.24 \mathrm{~g}(29.8 \mathrm{mmol}$, quant.) of 6 as a golden oil: ${ }^{1} \mathrm{H}$ NMR $\delta$ 7.30-7.22 (m, $\left.4 \mathrm{H}\right), 7.06-6.91(\mathrm{~m}, 6 \mathrm{H}), 5.93$ (ddt, $1 \mathrm{H}, J=14.7,9.9,4.5$ $\mathrm{Hz}), 5.26(\mathrm{~d}, 1 \mathrm{H}, J=17.4 \mathrm{~Hz}) 5.15(\mathrm{~d}, 1 \mathrm{H}, J=10.2 \mathrm{~Hz}), 4.40-4.34(\mathrm{~m}, 2 \mathrm{H}) ;{ }^{13} \mathrm{C} \mathrm{NMR} \delta 148.0$, $134.4,129.4,121.4,120.9,116.6,54.9$.

\section{3-(Diphenylamino)propane-1,2-diol. General protocol B}


To a solution of $4.86 \mathrm{~g}$ (23.2 mmol) of $N$-allyl- $N$-phenylaniline 6 in $75 \mathrm{~mL}$ of a THF/acetone/pH 7.0 phosphate buffer solution $(1: 1: 1)$ was added $3.53 \mathrm{~g}(30.1 \mathrm{mmol})$ of NMO and $700 \mu \mathrm{L}$ of $\mathrm{OsO}_{4}(1 \mathrm{~mol} \%, 0.33 \mathrm{M}$ in toluene). The reaction mixture was stirred overnight, quenched with a sodium bisulfite solution and extracted with $3 \times 20 \mathrm{~mL}$ of EtOAc. The combined organic layers were dried $\left(\mathrm{MgSO}_{4}\right)$ and concentrated in vacuo to afford a white solid which was recrystallized from hexanes/EtOAc to afford $4.85 \mathrm{~g}$ (19.9 mmol, 86\%) of 3-(diphenylamino)propane-1,2-diol as a white solid: Mp 96-98 ${ }^{\circ} \mathrm{C}$; IR (KBr) 3297, 2927, 1589, 1497, 1323, $1070 \mathrm{~cm}^{-1}$; ${ }^{1} \mathrm{H}$ NMR $\delta$ 7.28-7.22 (m, 4 H), 7.04-6.94 (m, 6 H), 4.05-3.95 (m, 1 H), 3.85-3.79 (m, 2 H), 3.73 (dd, 1 H, $J$ $=10.6,2.1 \mathrm{~Hz}), 3.55(\mathrm{dd}, 1 \mathrm{H}, J=11.1,5.4 \mathrm{~Hz}), 2.62(\mathrm{bs}, 1 \mathrm{H}), 2.21(\mathrm{bs}, 1 \mathrm{H}) ;{ }^{13} \mathrm{C}$ NMR $\delta$ 148.5, 129.6, 122.2, 121.6, 69.7, 64.4, 55.1; MS (EI) $\mathrm{m} / z 243\left(\mathrm{M}^{+}, 18\right), 182$ (100), 167 (13), 91 (87); HRMS (EI) $m / z$ calcd for $\mathrm{C}_{15} \mathrm{H}_{17} \mathrm{NO}_{2} 243.1259$, found 243.1260 .

$\boldsymbol{N}$-(Oxiran-2-ylmethyl)- $\boldsymbol{N}$-phenylaniline (1a). ${ }^{19}$ According to a modified literature procedure, ${ }^{19}$ a solution of $2.39 \mathrm{~g}$ (9.82 mmol) of 3-(diphenylamino)propane-1,2-diol in $32 \mathrm{~mL}$ of THF was cooled to $0{ }^{\circ} \mathrm{C}$ and treated with $3.84 \mathrm{~g}(11.7 \mathrm{mmol})$ of $p$ - $\mathrm{Ts}_{2} \mathrm{O}$ followed by $545 \mathrm{mg}(21.6 \mathrm{mmol})$ of $\mathrm{NaH}(95 \%)$. The reaction mixture was stirred at $0{ }^{\circ} \mathrm{C}$ for $3 \mathrm{~h}$, and an additional $1.17 \mathrm{~g}(29.4$ $\mathrm{mmol})$ of $\mathrm{NaH}(60 \%$ dispersion in mineral oil) was added. The solution was allowed to stir overnight at $\mathrm{rt}$, cooled to $0{ }^{\circ} \mathrm{C}$, and quenched with $\mathrm{H}_{2} \mathrm{O}$. The mixture was extracted with $3 \times 20$ $\mathrm{mL}$ of EtOAc. The combined organic layers were dried $\left(\mathrm{MgSO}_{4}\right)$, concentrated in vacuo and purified by chromatography on $\mathrm{SiO}_{2}$ (hexanes/EtOAc; 6:1) to afford $1.26 \mathrm{~g}(5.59 \mathrm{mmol}, 57 \%$ ) of 1a as a colorless oil: IR (neat) 3057, 2995, 2919, 1588, 1493, 1362, 1255, $748 \mathrm{~cm}^{-1}$; ${ }^{1} \mathrm{H}$ NMR $\delta$ 7.25-7.19 (m, $4 \mathrm{H}), 7.05-7.00(\mathrm{~m}, 4 \mathrm{H}), 6.93(\mathrm{tt}, 2 \mathrm{H}, J=7.2,0.1 \mathrm{~Hz}), 3.91(\mathrm{dd}, 1 \mathrm{H}, J=15.9,3.6$ Hz), 3.79 (dd, $1 \mathrm{H}, J=15.6,4.8 \mathrm{~Hz}), 3.19-3.14$ (m, $1 \mathrm{H}), 2.70$ (app t, $1 \mathrm{H}, J=4.8 \mathrm{~Hz}), 2.50$ (dd, $1 \mathrm{H}, J=5.1,2.7 \mathrm{~Hz}) ;{ }^{13} \mathrm{C}$ NMR $\delta 148.0,129.4,121.7,121.1,53.9,50.4,45.9$; MS (EI) $m / z 225$ $\left(\mathrm{M}^{+}, 36\right), 182$ (100), 167 (15), 104 (23); HRMS (EI) $\mathrm{m} / z$ calcd for $\mathrm{C}_{15} \mathrm{H}_{15} \mathrm{NO} 225.1153$, found 225.1145 .

(1-Phenylindolin-3-yl)methanol (2a) and 1-phenyl-1,2,3,4-tetrahydroquinolin-3-ol (3a). General protocol $\mathbf{C}$

To a 3-neck flask was added $273 \mathrm{mg}(1.21 \mathrm{mmol})$ of $1 \mathrm{a}, 9.0 \mathrm{mg}(0.03 \mathrm{mmol})$ of $\mathrm{Cp}_{2} \mathrm{TiCl}_{2}, 286$ $\mathrm{mg}(1.81 \mathrm{mmol})$ of collidine hydrochloride, and $99 \mathrm{mg}(1.81 \mathrm{mmol})$ of $\mathrm{Mn}$ powder. The vessel was fitted with a reflux condenser, and purged 3 times with Ar. After addition of $12.1 \mathrm{~mL}$ of THF $(0.1 \mathrm{M})$, the reaction mixture was heated at reflux for $45 \mathrm{~min}$. The color gradually changed from light orange to deep violet/blue. The mixture was cooled to rt, quenched with satd. $\mathrm{NH}_{4} \mathrm{Cl}$ and extracted with $3 \times 10 \mathrm{~mL}$ of $\mathrm{Et}_{2} \mathrm{O}$. The combined organic layers were dried $\left(\mathrm{MgSO}_{4}\right)$, and concentrated in vacuo. The residue was purified by chromatography on neutral alumina (hexanes:EtOAc; $3: 1$ to $1: 3$ ) to afford $237 \mathrm{mg}(1.05 \mathrm{mmol}, 87 \%)$ of $\mathbf{2 a}$ and $\mathbf{3 a}$ as a 3.8:1 mixture based on the integration of ${ }^{1} \mathrm{H}$ NMR peaks at $4.10 \mathrm{ppm}$ for $\mathbf{2 a}$ vs $3.15 \mathrm{ppm}$ for $\mathbf{3 a}$.

2a. ${ }^{1} \mathrm{H}$ NMR $\delta$ 7.35-6.93 (m, $\left.9 \mathrm{H}\right), 6.75$ (t, $1 \mathrm{H}, J=7.2 \mathrm{~Hz}$ ), 4.10 (app t, $1 \mathrm{H}, J=7.8 \mathrm{~Hz}$ ), 3.87$3.80(\mathrm{~m}, 2 \mathrm{H}), 3.57-3.48(\mathrm{~m}, 1 \mathrm{H}), 1.52(\mathrm{t}, 1 \mathrm{H}, J=4.2 \mathrm{~Hz}) ;{ }^{13} \mathrm{C} \mathrm{NMR} \delta 147.5,144.1,131.2$, $129.4,128.3,125.0,121.4,119.1,117.9,108.8,65.3,55.4,43.0$. 
3a: ${ }^{1} \mathrm{H}$ NMR $\delta$ 7.35-6.67 (m, $\left.9 \mathrm{H}\right), 4.38-4.28$ (m, $\left.1 \mathrm{H}\right), 3.72(\mathrm{bd}, 1 \mathrm{H}, J=11.1 \mathrm{~Hz}), 3.55$ (ddd, 1 $\mathrm{H}, J=11.7,4.5,1.5 \mathrm{~Hz}), 3.15$ (dd, $1 \mathrm{H}, J=16.5,4.2 \mathrm{~Hz}), 2.88$ (dd, $1 \mathrm{H}, J=16.5,4.8 \mathrm{~Hz}$ ), 2.13 $(\mathrm{d}, 1 \mathrm{H}, J=7.8 \mathrm{~Hz}) ;{ }^{13} \mathrm{C} \mathrm{NMR} \delta 147.4,143.9,130.5,129.6,126.8,125.2,124.5,120.8,119.0$, $115.0,64.3,56.4,36.2$.

$\mathrm{N}$-(2-Methylallyl)- $\mathrm{N}$-phenylaniline. According to General Protocol A, $4.20 \mathrm{~g}$ (24.8 mmol) of diphenylamine, $6.86 \mathrm{~g}(49.6 \mathrm{mmol})$ of $\mathrm{K}_{2} \mathrm{CO}_{3}, 4.0 \mathrm{~mL}$ (39.7 mmol) of 3-bromo-2methylpropene, and $1.83 \mathrm{~g}(4.96 \mathrm{mmol})$ of TBAI (reaction time $24 \mathrm{~h})$ afforded $3.17 \mathrm{~g}(14.1$ mmol, 57\%) of $N$-(2-methylallyl)- $N$-phenylaniline as a colorless oil: IR (neat) 3061, 3035, 2912, 2849, 2358, 1938, 1589, 1495, 1363, 1228, 894, $747 \mathrm{~cm}^{-1} ;{ }^{1} \mathrm{H}$ NMR $\delta 7.18$ (t, $\left.4 \mathrm{H}, J=7.5 \mathrm{~Hz}\right)$, 7.00 (bd, $4 \mathrm{H}, J=8.1 \mathrm{~Hz}$ ), 6.87 (bt, $2 \mathrm{H}, J=6.9 \mathrm{~Hz}$ ), 4.99 (bs, $1 \mathrm{H}), 4.86-4.86$ (m, $1 \mathrm{H}), 4.19$ (s, $2 \mathrm{H}), 1.70(\mathrm{~s}, 3 \mathrm{H}) ;{ }^{13} \mathrm{C}$ NMR $\delta 148.2,141.4,129.3,121.3,120.6,111.3,58.4,20.3$; MS (EI) $\mathrm{m} / \mathrm{z}$ $223\left(\mathrm{M}^{+}, 75\right), 208$ (19), 182 (100), 168 (57); HRMS (EI) $m / z$ calcd for $\mathrm{C}_{16} \mathrm{H}_{17} \mathrm{~N} 223.1361$, found 223.1351 .

3-(Diphenylamino)-2-methylpropane-1,2-diol. According to General Protocol B, $1.61 \mathrm{~g}$ (7.20 mmol) of $N$-(2-methylallyl)- $N$-phenylaniline, $1.26 \mathrm{~g}(10.8 \mathrm{mmol})$ of $\mathrm{NMO}$ and $218 \mu \mathrm{L}$ of $\mathrm{OsO}_{4}$ (1 mol\%, $0.33 \mathrm{M}$ in toluene) produced a brown solid that was recrystallized from chloroform/hexane to afford $1.55 \mathrm{~g}(6.05 \mathrm{mmol}, 84 \%)$ of 3-(diphenylamino)-2-methylpropane1,2-diol as a white solid: $\mathrm{Mp} \mathrm{67-68}{ }^{\circ} \mathrm{C}$; IR (KBr) 3445, 3057, 2927, 2873, 1588, 1494, 1363, 1240, 1035, $749 \mathrm{~cm}^{-1} ;{ }^{1} \mathrm{H}$ NMR $\left(\mathrm{CD}_{2} \mathrm{Cl}_{2}\right) \delta$ 7.35-7.20 (m, $\left.4 \mathrm{H}\right), 7.14-6.92(\mathrm{~m}, 6 \mathrm{H}), 3.97,3.84$ (AB, $2 \mathrm{H}, J=15.4 \mathrm{~Hz}), 3.50-3.32(\mathrm{~m}, 2 \mathrm{H}), 2.27$ (bs, $1 \mathrm{H}), 1.86$ (dd, $1 \mathrm{H}, J=6.0,1.2 \mathrm{~Hz}), 1.13$ $(\mathrm{s}, 3 \mathrm{H}) ;{ }^{13} \mathrm{C} \mathrm{NMR}\left(\mathrm{CD}_{2} \mathrm{Cl}_{2}\right) \delta 150.1,129.7,122.2,122.0,74.6,68.6,59.8,23.4$; MS (EI) $\mathrm{m} / z$ $257\left(\mathrm{M}^{+}, 10\right), 182$ (100), 169 (15), 104 (16); HRMS (EI) $m / z$ calcd for $\mathrm{C}_{16} \mathrm{H}_{19} \mathrm{NO}_{2} 257.1415$, found 257.1419 .

$\boldsymbol{N}$-((2-Methyloxiran-2-yl)methyl)- $\boldsymbol{N}$-phenylaniline (1b). To a solution of $430 \mathrm{mg}(1.67 \mathrm{mmol})$ of 3-(diphenylamino)-2-methylpropane-1,2-diol in $16 \mathrm{~mL}$ of THF at $0{ }^{\circ} \mathrm{C}$ was added $267 \mathrm{mg}$ $(6.68 \mathrm{mmol})$ of $\mathrm{NaH}(60 \%$ dispersion in mineral oil). The mixture was stirred for $10 \mathrm{~min}$ and 597 $\mathrm{mg}(1.83 \mathrm{mmol})$ of $p$ - $\mathrm{Ts}_{2} \mathrm{O}$ dissolved in $3 \mathrm{~mL}$ of THF was added dropwise. The disappearance of starting material was monitored by TLC (hexanes:EtOAc; 2:1). The reaction mixture was quenched with $\mathrm{H}_{2} \mathrm{O}$ and extracted with $3 \times 10 \mathrm{~mL}$ of $\mathrm{Et}_{2} \mathrm{O}$. The combined organic layers were dried $\left(\mathrm{MgSO}_{4}\right)$, concentrated in vacuo and purified by chromatography on $\mathrm{SiO}_{2}$ (hexanes:EtOAc; 10:1) to afford $279 \mathrm{mg}(1.16 \mathrm{mmol}, 70 \%)$ of $\mathbf{1 b}$ as a colorless oil: IR (neat) 3037, 2982, 2924, 1588, 1495, 1362, 1242, $749 \mathrm{~cm}^{-1} ;{ }^{1} \mathrm{H}$ NMR $\left(\mathrm{CD}_{2} \mathrm{Cl}_{2}\right) \delta$ 7.31-7.23 (m, $\left.4 \mathrm{H}\right), 7.05-6.93(\mathrm{~m}, 6 \mathrm{H})$, 3.96, $3.90(\mathrm{AB}, 2 \mathrm{H}, J=16.0 \mathrm{~Hz}), 2.68(\mathrm{~d}, 1 \mathrm{H}, J=4.8 \mathrm{~Hz}), 2.57$ (d, $1 \mathrm{H}, J=4.8 \mathrm{~Hz}), 1.38$ (s, 3 $\mathrm{H}) ;{ }^{13} \mathrm{C}$ NMR $\left(\mathrm{CD}_{2} \mathrm{Cl}_{2}\right) \delta 148.9,129.6,121.8,121.3,57.1,56.8,52.4,19.8 ; \mathrm{MS}(\mathrm{EI}) \mathrm{m} / z 239$ $\left(\mathrm{M}^{+}, 30\right), 182$ (100), 167 (15), 104 (23); HRMS (EI) $\mathrm{m} / z$ calcd for $\mathrm{C}_{16} \mathrm{H}_{17} \mathrm{NO} 239.1310$, found 239.1311 .

(3-Methyl-1-phenylindolin-3-yl)methanol (2b). According to General Protocol C, $71 \mathrm{mg}(0.29$ mmol) of $1 \mathbf{b}, 2.2 \mathrm{mg}(0.08 \mathrm{mmol})$ of $\mathrm{Cp}_{2} \mathrm{TiCl}_{2}, 69 \mathrm{mg}(0.44 \mathrm{mmol})$ of collidine hydrochloride and $24 \mathrm{mg}(0.44 \mathrm{mmol})$ of $\mathrm{Mn}$ powder provided a mixture (reaction time $25 \mathrm{~min}$ ) that was purified by chromatography on neutral alumina (hexanes:EtOAc; $6: 1$ to EtOAc:EtOH; 5:1) to 
afford $63 \mathrm{mg}(0.26 \mathrm{mmol}, 89 \%)$ of $\mathbf{2 b}$ as a colorless oil: IR (neat) 3360, 3057, 2959, 2925, 2866, 1591, 1501, 1462, 1385, 1024, $744 \mathrm{~cm}^{-1} ;{ }^{1} \mathrm{H}$ NMR $\delta 7.32$ (t, $\left.2 \mathrm{H}, J=7.5 \mathrm{~Hz}\right), 7.22$ (d, $1 \mathrm{H}, J=$ $7.6 \mathrm{~Hz}), 7.15$ (dt, $2 \mathrm{H}, J=1.2,6.9 \mathrm{~Hz}), 7.10$ (bt, $2 \mathrm{H}, J=6.9 \mathrm{~Hz}), 6.95$ (t, $1 \mathrm{H}, J=7.2 \mathrm{~Hz}), 6.77$ (t, $1 \mathrm{H}, J=6.9 \mathrm{~Hz}), 3.91,3.66(\mathrm{AB}, 2 \mathrm{H}, J=9.4 \mathrm{~Hz}), 3.63(\mathrm{~A}$ of ABX, $1 \mathrm{H}, J=6.0,10.5 \mathrm{~Hz}$ ), $3.56(\mathrm{~B}$ of $\mathrm{ABX}, 1 \mathrm{H}, J=6.3,10.5 \mathrm{~Hz}), 1.70-1.65(\mathrm{~m}, 1 \mathrm{H}), 1.37(\mathrm{~s}, 3 \mathrm{H}) ;{ }^{13} \mathrm{C} \mathrm{NMR} \delta 146.9$, 144.0, 135.6, 129.4, 128.2, 123.4, 121.2, 119.1, 117.8, 108.7, 69.1, 61.8, 45.6, 22.5; MS (EI) $\mathrm{m} / z$ $239\left(\mathrm{M}^{+}, 23\right), 208$ (100), 193 (25), 130 (10); HRMS (EI) m/z calcd for $\mathrm{C}_{16} \mathrm{H}_{17} \mathrm{NO} 239.1310$, found 239.1318 .

\section{Benzyl phenylcarbamate. ${ }^{20}$ General protocol D}

According to a modified literature procedure, ${ }^{20}$ a solution of $2.04 \mathrm{~g}(21.9 \mathrm{mmol})$ of aniline in 50 $\mathrm{mL}$ of THF at $0{ }^{\circ} \mathrm{C}$ was treated with $2.02 \mathrm{~g}(24.0 \mathrm{mmol})$ of $\mathrm{NaHCO}_{3}$ followed by $3.4 \mathrm{~mL}(24.0$ mmol) of benzyl chloroformate. After 15, min the reaction mixture was warmed to rt, quenched with $\mathrm{H}_{2} \mathrm{O}$ and extracted with $3 \times 20 \mathrm{~mL}$ of EtOAc. The combined organic layers were dried $\left(\mathrm{MgSO}_{4}\right)$ and concentrated in vacuo to afford $4.97 \mathrm{~g}$ (21.9 mmol, quant.) of benzyl phenylcarbamate as a white solid that was used without further purification: Mp $76-77{ }^{\circ} \mathrm{C} ;{ }^{1} \mathrm{H}$ NMR $\delta$ 7.40-7.20 (m, $9 \mathrm{H}), 7.01(\mathrm{t}, 1 \mathrm{H}, J=7.2 \mathrm{~Hz}), 6.94(\mathrm{bs}, 1 \mathrm{H}), 5.13(\mathrm{~s}, 2 \mathrm{H}) ;{ }^{13} \mathrm{C}$ NMR $\delta$ $153.6,138.0,136.2,129.1,128.7,128.4,123.6,118.9,67.1$.

\section{Benzyl (2-methyloxiran-2-yl)methyl(phenyl)carbamate (1c). General protocol E}

To a solution of $2.91 \mathrm{~g}(12.8 \mathrm{mmol})$ of benzyl phenylcarbamate in $60 \mathrm{~mL}$ of $\mathrm{THF}$ at $0{ }^{\circ} \mathrm{C}$ was added $1.02 \mathrm{~g}(25.6 \mathrm{mmol})$ of $\mathrm{NaH}(60 \%$ dispersion in mineral oil $)$. The reaction mixture was warmed to rt over $15 \mathrm{~min}$ and $2.6 \mathrm{~mL}(25.6 \mathrm{mmol})$ of 3-bromo-2-methylpropene were added. The solution was stirred overnight, quenched with $\mathrm{H}_{2} \mathrm{O}$ and extracted with $3 \times 20 \mathrm{~mL}$ of $\mathrm{Et}_{2} \mathrm{O}$. The combined organic layers were dried $\left(\mathrm{MgSO}_{4}\right)$ and concentrated in vacuo. The residue was dissolved in $80 \mathrm{~mL}$ of dichloromethane, cooled to $0{ }^{\circ} \mathrm{C}$ and $5.67 \mathrm{~g}(23.0 \mathrm{mmol})$ of $m$-CPBA $(70 \%)$ was added portionwise. The reaction mixture was quenched with aq. $\mathrm{Na}_{2} \mathrm{~S}_{2} \mathrm{O}_{3}$ solution and extracted with $3 \times 10 \mathrm{~mL}$ of $\mathrm{Et}_{2} \mathrm{O}$. The combined organic layers were dried $\left(\mathrm{MgSO}_{4}\right)$, concentrated in vacuo and purified by chromatography on $\mathrm{SiO}_{2}$ (hexanes:EtOAc; 4:1 with 1\% $\left.\mathrm{NEt}_{3}\right)$ to afford $3.01 \mathrm{~g}(10.1 \mathrm{mmol}, 79 \%, 2$ steps) of $\mathbf{1 c}$ as an orange oil: IR (neat) 3520, 3036, 2934, 2360, 1706, 1597, 1494, 1405, 1273, 1147, $1020 \mathrm{~cm}^{-1} ;{ }^{1} \mathrm{H}$ NMR $\delta 7.38-7.20$ (m, $\left.10 \mathrm{H}\right)$, $5.14(\mathrm{~s}, 2 \mathrm{H}), 3.95,3.72(\mathrm{AB}, 2 \mathrm{H}, J=14.7 \mathrm{~Hz}), 2.50,2.47(\mathrm{AB}, 2 \mathrm{H}, J=4.8 \mathrm{~Hz}), 1.36(\mathrm{~s}, 3 \mathrm{H})$; ${ }^{13} \mathrm{C}$ NMR $\delta 155.6,142.2,136.5,129.0,128.4,128.0,127.6,127.2,126.9,67.5,55.7,55.5,52.5$, 19.4; MS (EI) m/z $297\left(\mathrm{M}^{+}, 23\right), 196$ (71), 132 (47), 91 (100); HRMS (EI) $\mathrm{m} / z$ calcd for $\mathrm{C}_{18} \mathrm{H}_{19} \mathrm{NO}_{3} 297.1364$, found 297.1351.

Benzyl 3-(hydroxymethyl)-3-methylindoline-1-carboxylate (2c). A solution of $85 \mathrm{mg}(0.28$ $\mathrm{mmol})$ of $1 \mathrm{c}, 7.0 \mathrm{mg}(0.02 \mathrm{mmol})$ of $\mathrm{Cp}_{2} \mathrm{TiCl}_{2}, 179 \mathrm{mg}(1.14 \mathrm{mmol})$ of collidine hydrochloride, and $23.5 \mathrm{mg}(0.42 \mathrm{mmol})$ of Mn powder in $2.8 \mathrm{~mL}$ of THF was stirred for $5 \mathrm{~h}$ at $\mathrm{rt}$, quenched with satd. $\mathrm{NH}_{4} \mathrm{Cl}$ and extracted with $3 \times 5 \mathrm{~mL}$ of $\mathrm{Et}_{2} \mathrm{O}$. The combined organic layers were dried $\left(\mathrm{MgSO}_{4}\right)$ and concentrated in vacuo to provide a residue containing $\mathbf{2 c}$ and $\mathbf{4 c}(\sim 2: 1$ ratio based 
on integration of the crude ${ }^{1} \mathrm{H}$ NMR peaks at $4.15 \mathrm{ppm}(\mathbf{2 c})$ vs $\left.0.88 \mathrm{ppm}(\mathbf{4 c})\right)$. The mixture was partially purified by chromatography on $\mathrm{SiO}_{2}$ (hexanes:EtOAc; 4:1) to afford $36 \mathrm{mg}(0.12 \mathrm{mmol}$, $42 \%$ ) of $2 \mathbf{c}$ in addition to $37 \mathrm{mg}$ of an inseparable mixture of $2 \mathbf{c}$ and $\mathbf{4 c}$.

2c: ${ }^{1} \mathrm{H}$ NMR $\delta 7.89$ (bs, $\left.1 \mathrm{H}\right), 7.49-6.97$ (m, $\left.8 \mathrm{H}\right), 5.24$ (bs, $\left.2 \mathrm{H}\right), 4.12$ (d, $\left.1 \mathrm{H}, J=11.8 \mathrm{~Hz}\right), 3.68$ (d, $1 \mathrm{H}, J=11.7 \mathrm{~Hz}), 3.61,3.53(\mathrm{AB}, 2 \mathrm{H}, J=10.8 \mathrm{~Hz}), 1.70$ (bs, $1 \mathrm{H}), 1.34$ (s, $3 \mathrm{H})$; MS (EI) $\mathrm{m} / \mathrm{z} 297\left(\mathrm{M}^{+}, 28\right), 222$ (55), 130 (40), 91 (100).

4c: ${ }^{1} \mathrm{H}$ NMR $\delta$ 7.44-7.41 (m, $\left.10 \mathrm{H}\right), 5.15,5.11(\mathrm{AB}, 2 \mathrm{H}, J=12.7 \mathrm{~Hz}), 3.96(\mathrm{dd}, 1 \mathrm{H}, J=14.4$, 9.6 Hz), 3.71-3.30 (m, $3 \mathrm{H}), 1.86-1.70(\mathrm{~m}, 1 \mathrm{H}), 0.89$ (d, $3 \mathrm{H}, J=6.9 \mathrm{~Hz})$; MS (EI) m/z $299\left(\mathrm{M}^{+}\right.$, 10), $191(20), 91(100)$.

\section{(3-Methylindolin-3-yl)methanol (7c). General protocol F}

To a 2-neck flask was added $129 \mathrm{mg}(0.43 \mathrm{mmol})$ of $1 \mathrm{c}, 3.2 \mathrm{mg}(0.01 \mathrm{mmol})$ of $\mathrm{Cp}_{2} \mathrm{TiCl}_{2}, 102$ $\mathrm{mg}(0.64 \mathrm{mmol})$ of collidine hydrochloride, and $35.6 \mathrm{mg}(0.64 \mathrm{mmol})$ of $\mathrm{Mn}$ powder. The vessel was fitted with a reflux condenser and purged $3 \mathrm{x}$ with argon. After addition of $4.3 \mathrm{~mL}$ of THF $(0.1 \mathrm{M})$, the reaction mixture was placed in a preheated oil bath and heated at reflux for $3 \mathrm{~h}$. During this time, the solution gradually changed from light pink to a dark violet color. The mixture was cooled to rt, quenched with satd. $\mathrm{NH}_{4} \mathrm{Cl}$ and extracted with $3 \times 10 \mathrm{~mL}$ of Et $\mathrm{t}_{2} \mathrm{O}$. The combined organic layers were washed with brine, dried $\left(\mathrm{MgSO}_{4}\right)$ and concentrated in vacuo. The residue was dissolved in $5 \mathrm{~mL}$ of $\mathrm{MeOH}$ and treated with $30 \mathrm{mg}(25 \% \mathrm{w} / \mathrm{w}, 0.01 \mathrm{mmol}) \mathrm{of} \mathrm{Pd} / \mathrm{C}$. The mixture was stirred at $\mathrm{rt}$ under 1 atm of $\mathrm{H}_{2}$ and the disappearance of starting material was monitored by TLC (hexanes:EtOAc; 1:1). The solution was then quenched with Celite, filtered and purified by chromatography on $\mathrm{SiO}_{2}$ (hexanes:EtOAc; 1:2) to afford $44 \mathrm{mg}(0.26 \mathrm{mmol}$, $63 \%, 2$ steps) of 7c as a yellow oil: IR (neat) 3332, 2959, 2926, 2867, 1606, 1487, 1461, 1239, 1030, 747 $\mathrm{cm}^{-1}$; ${ }^{1} \mathrm{H}$ NMR $\delta 7.08-7.02(\mathrm{~m}, 2 \mathrm{H}), 6.73(\mathrm{t}, 1 \mathrm{H}, J=6.6 \mathrm{~Hz}), 6.62(\mathrm{~d}, 1 \mathrm{H}, J=7.5$ $\mathrm{Hz}), 3.59,3.53(\mathrm{AB}, 2 \mathrm{H}, J=10.5 \mathrm{~Hz}), 3.55,3.26(\mathrm{AB}, 2 \mathrm{H}, J=9.0 \mathrm{~Hz}), 1.31(\mathrm{~s}, 3 \mathrm{H}) ;{ }^{13} \mathrm{C}$ NMR $\delta 151.7,133.7,128.4,123.2,118.9,110.0,69.4,57.0,47.7,22.4$; MS (EI) $m / z 163\left(\mathrm{M}^{+}, 32\right), 132$ (100), 117 (59); HRMS (EI) $\mathrm{m} / z$ calcd for $\mathrm{C}_{10} \mathrm{H}_{13} \mathrm{NO}$ 163.0997, found 163.0993.

Ethyl phenylcarbamate. ${ }^{21}$ According to a modified literature procedure, ${ }^{21}$ to a solution of 5.10 $\mathrm{g}(54.7 \mathrm{mmol})$ of aniline in $130 \mathrm{~mL}$ of THF at $0{ }^{\circ} \mathrm{C}$ was added $3.06 \mathrm{~g}(76.5 \mathrm{mmol})$ of $\mathrm{NaH}(60 \%$ dispersion in mineral oil) followed by $6.3 \mathrm{~mL}(65.7 \mathrm{mmol})$ of ethyl chloroformate. The reaction mixture was warmed to rt, quenched with $\mathrm{H}_{2} \mathrm{O}$ after $3 \mathrm{~h}$ and extracted with $3 \mathrm{x} 40 \mathrm{~mL}$ of Et $\mathrm{Et}_{2} \mathrm{O}$. The combined organic layers were dried $\left(\mathrm{MgSO}_{4}\right)$, concentrated in vacuo and purified by chromatography on $\mathrm{SiO}_{2}$ (hexanes:EtOAc; 5:1 to 3:1) to afford $8.07 \mathrm{~g}$ (48.8 mmol, 89\%) of ethyl phenylcarbamate as a brown oil: ${ }^{1} \mathrm{H}$ NMR $\delta$ 7.39-7.25 (m, $\left.4 \mathrm{H}\right), 7.05(\mathrm{t}, 1 \mathrm{H}, J=6.9 \mathrm{~Hz}), 6.59$ (bs, $1 \mathrm{H}), 4.22$ (q, $2 \mathrm{H}, J=7.2 \mathrm{~Hz}), 1.31$ (t, $3 \mathrm{H}, J=7.2 \mathrm{~Hz}$ ); MS (EI) $m / z 165\left(\mathrm{M}^{+}, 78\right), 119$ (34), 93 (100), 65 (50).

Ethyl (2-methyloxiran-2-yl)methyl(phenyl)carbamate (1d). According to General Procedure E, $2.54 \mathrm{~g}$ (15.4 mmol) of ethyl phenylcarbamate, $1.23 \mathrm{~g}(30.8 \mathrm{mmol})$ of $\mathrm{NaH}(60 \%$ dispersion in mineral oil), $2.8 \mathrm{~mL}(27.7 \mathrm{mmol})$ of 3-bromo-2-methylpropene, and $5.70 \mathrm{~g}(23.1 \mathrm{mmol}) \mathrm{of} \mathrm{m}$ CPBA (70\%) provided an oil that was purified by chromatography on $\mathrm{SiO}_{2}$ (hexanes:EtOAc; 
4:1) to afford $2.66 \mathrm{~g}$ (11.3 mmol, 73\%, 2 steps) of $\mathbf{1 d}$ as a golden oil: IR (neat) 3043, 2981, 2933, 1702, 1597, 1536, 1408, 1299, $1023 \mathrm{~cm}^{-1} ;{ }^{1} \mathrm{H}$ NMR $\delta$ 7.35-7.18 (m, $\left.5 \mathrm{H}\right), 4.14$ (q, $2 \mathrm{H}, J=6.9$ $\mathrm{Hz}$ ), 3.93 (A of ABX, $1 \mathrm{H}, J=14.7,0.6 \mathrm{~Hz}$ ), 3.71 (B of ABX, $1 \mathrm{H}, J=14.7,0.9 \mathrm{~Hz}$ ), 2.51 (bs, 2 $\mathrm{H}), 1.37(\mathrm{~s}, 3 \mathrm{H}), 1.19(\mathrm{t}, 3 \mathrm{H}, J=6.9 \mathrm{~Hz}) ;{ }^{13} \mathrm{C}$ NMR $\delta$ 155.8, 142.4, 128.9, 127.1, 126.6, 61.9, 55.7, 55.3, 52.5, 19.4, 14.5; MS (EI) m/z $235\left(\mathrm{M}^{+}, 45\right), 178$ (38), 134 (28), 106 (100); HRMS (EI) $m / z$ calcd for $\mathrm{C}_{13} \mathrm{H}_{17} \mathrm{NO}_{3} 235.1208$, found 235.1219 .

Ethyl 3-(hydroxymethyl)-3-methylindoline-1-carboxylate (2d). According to General Protocol C, $125 \mathrm{mg}(0.53 \mathrm{mmol})$ of $\mathbf{1 d}, 3.9 \mathrm{mg}(0.01 \mathrm{mmol})$ of $\mathrm{Cp}_{2} \mathrm{TiCl}_{2}, 125 \mathrm{mg}(0.79 \mathrm{mmol})$ of collidine hydrochloride, and $43 \mathrm{mg}(0.79 \mathrm{mmol})$ of $\mathrm{Mn}$ powder provided a mixture (reaction time $2 \mathrm{~h}$ ) that was purified by chromatography on $\mathrm{SiO}_{2}$ (hexanes:EtOAc; $\left.3: 1\right)$ to afford $81 \mathrm{mg}(0.34$ mmol, 65\%) of $\mathbf{2 d}$ as an oil: IR (neat) 3433, 2976, 2931, 1693, 1600,1487, 1413, 1051 $\mathrm{cm}^{-1} ;{ }^{1} \mathrm{H}$ NMR $\delta 7.85(\mathrm{bs}, 1 \mathrm{H}), 7.24(\mathrm{t}, 1 \mathrm{H}, J=6.9 \mathrm{~Hz}), 7.11(\mathrm{~d}, 1 \mathrm{H}, J=6.9 \mathrm{~Hz}), 6.98(\mathrm{t}, 1 \mathrm{H}, J=7.2$ Hz), 4.26 (bs, $2 \mathrm{H}), 4.07$ (d, $1 \mathrm{H}, J=11.4 \mathrm{~Hz}), 3.64$ (d, $1 \mathrm{H}, J=11.4 \mathrm{~Hz}), 3.61$ (dd, $1 \mathrm{H}, J=11.4$, $4.5 \mathrm{~Hz}), 3.52$ (dd, $1 \mathrm{H}, J=10.5,6.6 \mathrm{~Hz}), 1.97$ (bs, $1 \mathrm{H}), 1.34$ (bs, $6 \mathrm{H}) ;{ }^{13} \mathrm{C}$ NMR $\delta 153.6,142.9$, 135.8, 128.6, 123.0, 122.8, 115.1, 69.7, 61.7, 57.7, 45.4, 23.2, 14.8; MS (EI) $m / z 235\left(\mathrm{M}^{+}, 31\right)$, 204 (100), 160 (27), 130 (71), 117 (55); HRMS (EI) m/z calcd for $\mathrm{C}_{13} \mathrm{H}_{17} \mathrm{NO}_{3} 235.1208$, found 235.1202 .

Benzyl p-tolylcarbamate. $^{20 \mathrm{~b}}$ According to General Protocol D, $4.15 \mathrm{~g}(38.7 \mathrm{mmol})$ of $p$ toluidine, $3.57 \mathrm{~g}(42.6 \mathrm{mmol})$ of $\mathrm{NaHCO}_{3}$, and $6.0 \mathrm{~mL}(42.6 \mathrm{mmol})$ of benzyl chloroformate (reaction time $30 \mathrm{~min}$ ) afforded a solid that was recrystallized from chloroform/hexane to afford $8.12 \mathrm{~g}$ (33.6 mmol, 87\%) of benzyl p-tolylcarbamate as white needles: Mp 82-84 ${ }^{\circ} \mathrm{C}$; IR (KBr) $3319,3195,3032,2943,1730,1707,1602,1543,1406,1232,1067,739 \mathrm{~cm}^{-1}$; ${ }^{1} \mathrm{H}$ NMR $\delta 7.39-$ $7.20(\mathrm{~m}, 7 \mathrm{H}), 7.06(\mathrm{~d}, 2 \mathrm{H}, J=8.4 \mathrm{~Hz}), 6.72(\mathrm{bs}, 1 \mathrm{H}), 5.15(\mathrm{~s}, 2 \mathrm{H}), 2.27(\mathrm{~s}, 3 \mathrm{H}) ;{ }^{13} \mathrm{C}$ NMR $\delta$ 153.7, 136.3, 135.4, 133.2, 129.7, 128.7, 128.4, 119.1, 67.1, 20.9; MS (EI) m/z $241\left(\mathrm{M}^{+}, 49\right)$, 197 (45), 133 (34), 91 (100), 84 (91); HRMS (EI) $m / z$ calcd for $\mathrm{C}_{15} \mathrm{H}_{15} \mathrm{NO}_{2} 241.1102$, found 241.1106.

Benzyl (2-methyloxiran-2-yl)methyl(p-tolyl)carbamate (8a). According to General Protocol E, $4.42 \mathrm{~g}$ (18.3 mmol) of benzyl p-tolylcarbamate, $1.46 \mathrm{~g}(36.6 \mathrm{mmol})$ of $\mathrm{NaH}(60 \%$ dispersion in mineral oil), $2.8 \mathrm{~mL}(27.4 \mathrm{mmol})$ of 3-bromo-2-methylpropene, and $6.76 \mathrm{~g}(27.4 \mathrm{mmol})$ of $\mathrm{m}$ CPBA $(70 \%)$ provided an oil that was purified by chromatography on $\mathrm{SiO}_{2}$ (hexanes:EtOAc; 4:1) to afford $4.43 \mathrm{~g}$ (14.2 mmol, 78\%, 2 steps) of 8a as a red oil: IR (neat) 3583, 3033, 2929, 1702, 1514, 1404, 1271, $1146 \mathrm{~cm}^{-1} ;{ }^{1} \mathrm{H}$ NMR $\delta$ 7.33-7.24 (m, $\left.5 \mathrm{H}\right), 7.16-7.09$ (m, $\left.4 \mathrm{H}\right), 5.14$ (bs, $2 \mathrm{H}), 3.91,3.69$ (AB, $2 \mathrm{H}, J=14.7 \mathrm{~Hz}), 2.50,2.47$ (AB, $2 \mathrm{H}, J=4.6 \mathrm{~Hz}), 2.33$ (s, $3 \mathrm{H}), 1.35$ (s, 3 $\mathrm{H}) ;{ }^{13} \mathrm{C}$ NMR $\delta 155.9,139.7,136.8,136.7,129.8,128.6,128.1,127.8,127.1,67.6,55.9,55.8$, 52.7, 21.2, 19.5; MS (EI) m/z $311\left(\mathrm{M}^{+}, 35\right), 210$ (46), 146 (48), 91 (95), 84 (100); HRMS (EI) $m / z$ calcd for $\mathrm{C}_{19} \mathrm{H}_{21} \mathrm{NO}_{3} 311.1521$, found 311.1525 .

(3,5-Dimethylindolin-3-yl)methanol (9a). According to General Protocol F, $163 \mathrm{mg}(0.52$ $\mathrm{mmol})$ of $11,3.9 \mathrm{mg}(0.01 \mathrm{mmol})$ of $\mathrm{Cp}_{2} \mathrm{TiCl}_{2}, 123 \mathrm{mg}(0.78 \mathrm{mmol})$ of collidine hydrochloride, and $43 \mathrm{mg}(0.78 \mathrm{mmol})$ of Mn powder provided an oil (reaction time $3 \mathrm{~h}$ ) that was purified first by chromatography on neutral alumina (hexanes:EtOAc; $2: 1)$ and then subjected to $111 \mathrm{mg}(70 \%$ 
w/w, $0.05 \mathrm{mmol}$ ) of $\mathrm{Pd} / \mathrm{C}$ under $1 \mathrm{~atm}$ of $\mathrm{H}_{2}$ (reaction time $2 \mathrm{~h}$ ) to provide an oil that was purified by chromatography on $\mathrm{SiO}_{2}$ (hexanes:EtOAc; $1: 1$ with $\left.1 \% \mathrm{NEt}_{3}\right)$ to afford $57 \mathrm{mg}(0.32$ mmol, 62\%, 2 steps) of 9a as an oil: IR (neat) 3327, 2958, 2922, 2864, 1614, 1495, 1463, 1238, $1033,810 \mathrm{~cm}^{-1}$; ${ }^{1} \mathrm{H}$ NMR $\delta$ 6.87-6.85 (m, $\left.2 \mathrm{H}\right), 6.56-6.53(\mathrm{~m}, 1 \mathrm{H}), 3.58,3.51(\mathrm{AB}, 2 \mathrm{H}, J=10.6$ $\mathrm{Hz}), 3.53,3.22(\mathrm{AB}, 2 \mathrm{H}, J=9.1 \mathrm{~Hz}), 2.25(\mathrm{~s}, 3 \mathrm{H}), 1.30(\mathrm{~s}, 3 \mathrm{H}) ;{ }^{13} \mathrm{C} \mathrm{NMR} \delta 149.3,134.1$, 128.7, 128.4, 123.8, 110.1, 69.4, 57.3, 47.7, 22.3, 21.0; MS (EI) $m / z 177\left(\mathrm{M}^{+}, 45\right), 146$ (100), 131 (69), 130 (38); HRMS (EI) $m / z$ calcd for $\mathrm{C}_{11} \mathrm{H}_{15} \mathrm{NO} 177.1153$, found 177.1154.

Benzyl o-tolylcarbamate. According to General Protocol D, $3.81 \mathrm{~g}(35.5 \mathrm{mmol})$ of $o$-toluidine, $3.28 \mathrm{~g}(39.1 \mathrm{mmol})$ of $\mathrm{NaHCO}_{3}$, and $5.5 \mathrm{~mL}(39.1 \mathrm{mmol})$ of benzyl chloroformate (reaction time $1 \mathrm{~h}$ ) provided a solid that was recrystallized from $\mathrm{Et}_{2} \mathrm{O}$ to afford $7.41 \mathrm{~g}(30.7 \mathrm{mmol}, 86 \%)$ of benzyl $o$-tolylcarbamate as a white solid: $\mathrm{Mp} 83-84{ }^{\circ} \mathrm{C}$; IR $(\mathrm{KBr}) 3297,3036,2959,1695,1588$, 1533, 1454, 1294, 1240, $1064 \mathrm{~cm}^{-1} ;{ }^{1} \mathrm{H}$ NMR (DMSO- $d_{6}, 350 \mathrm{~K}$ ) $\delta 8.64$ (bs, $\left.1 \mathrm{H}\right), 7.47-7.30$ (m, $6 \mathrm{H}), 7.20-7.09(\mathrm{~m}, 3 \mathrm{H}), 5.16(\mathrm{~s}, 2 \mathrm{H}), 2.33(\mathrm{~s}, 3 \mathrm{H}) ;{ }^{13} \mathrm{C}$ NMR (DMSO-d, $\left.350 \mathrm{~K}\right) \delta 153.9$, 136.6, 136.0, 131.3, 129.8, 127.9, 127.3, 127.2, 125.5, 124.4, 124.2, 65.3, 17.1; MS (EI) $m / z 241$ $\left(\mathrm{M}^{+}, 13\right), 197$ (13), 133 (18), 104 (16), 91 (100); HRMS (EI) $\mathrm{m} / z$ calcd for $\mathrm{C}_{15} \mathrm{H}_{15} \mathrm{NO}_{2} 241.1102$, found 241.1107.

Benzyl (2-methyloxiran-2-yl)methyl(o-tolyl)carbamate (8b). According to General Protocol E, $3.60 \mathrm{~g}(14.9 \mathrm{mmol})$ of benzyl $o$-tolylcarbamate, $1.19 \mathrm{~g}(29.8 \mathrm{mmol})$ of $\mathrm{NaH}(60 \%$ dispersion in mineral oil), $2.2 \mathrm{~mL}$ (22.3 mmol) of 3-bromo-2-methylpropene, and $5.51 \mathrm{~g}$ (22.3 mmol) of $\mathrm{m}$ CPBA (70\%) provided an oil that was purified by chromatography on $\mathrm{SiO}_{2}$ (hexanes:EtOAc; $4: 1)$ to afford $3.88 \mathrm{~g}(12.4 \mathrm{mmol}, 84 \%, 2$ steps) of $\mathbf{8 b}$ as an oil: IR (neat) 3033, 2931, 1708, 1583, 1493, 1406, 1299, 1147, $1028 \mathrm{~cm}^{-1}$; ${ }^{1} \mathrm{H}$ NMR (DMSO-d $\left.6,350 \mathrm{~K}\right) \delta$ 7.34-7.20 (m, $\left.9 \mathrm{H}\right), 5.09(\mathrm{~s}, 2$ $\mathrm{H}), 4.10-3.20$ (br m, $2 \mathrm{H}), 2.50,2.41(\mathrm{AB}, 2 \mathrm{H}, J=4.7 \mathrm{~Hz}), 2.13(\mathrm{~s}, 3 \mathrm{H}), 1.32(\mathrm{~s}, 3 \mathrm{H}) ;{ }^{13} \mathrm{C}$ NMR (DMSO- $\left.d_{6}, 350 \mathrm{~K}\right) \delta 154.6,140.7,136.3,134.9,130.2,127.9,127.8,127.3,126.9,126.8$, 126.0, 66.3, 54.7, 51.2, 18.9, 16.6; MS (EI) m/z $311\left(\mathrm{M}^{+}, 15\right), 210$ (8), 118 (25), 91 (100); HRMS (EI) $m / z$ calcd for $\mathrm{C}_{19} \mathrm{H}_{21} \mathrm{NO}_{3} 311.1521$, found 311.1527 .

(3,7-Dimethylindolin-3-yl)methanol (9b). According to General Protocol F, $230 \mathrm{mg}(0.73$ $\mathrm{mmol})$ of $13,7.3 \mathrm{mg}(0.02 \mathrm{mmol})$ of $\mathrm{Cp}_{2} \mathrm{TiCl}_{2}, 174 \mathrm{mg}(1.10 \mathrm{mmol})$ of collidine hydrochloride, and $60 \mathrm{mg}(1.10 \mathrm{mmol})$ of $\mathrm{Mn}$ powder (reaction time $5 \mathrm{~h}$ ) provided an oil that was purified by chromatography on neutral alumina (hexanes:EtOAc; $4: 1)$ and then subjected to $10 \mathrm{mg}(10 \%$ $\mathrm{w} / \mathrm{w}, 4.6 \mu \mathrm{mol}$ ) of $\mathrm{Pd} / \mathrm{C}$ under 1 atm of $\mathrm{H}_{2}$ to provide a mixture that was purified by chromatography on $\mathrm{SiO}_{2}$ (hexanes:EtOAc; 4:1 with 1\% $\left.\mathrm{NEt}_{3}\right)$ to afford $46 \mathrm{mg}(0.25 \mathrm{mmol}, 35 \%$, 2 steps) of 9b as an oil: IR (neat) 3317, 2960, 2926, 2867, 1599, 1478, 1030, $749 \mathrm{~cm}^{-1}$; ${ }^{1} \mathrm{H}$ NMR $\delta 6.91(\mathrm{~d}, 2 \mathrm{H}, J=7.5 \mathrm{~Hz}), 6.69$ (t, $1 \mathrm{H}, J=7.5 \mathrm{~Hz}), 3.61,3.54(\mathrm{AB}, 2 \mathrm{H}, J=10.5 \mathrm{~Hz}), 3.60(\mathrm{~d}, 1$ $\mathrm{H}, J=9.3 \mathrm{~Hz}), 3.29(\mathrm{~d}, 1 \mathrm{H}, J=9.3 \mathrm{~Hz}), 2.12(\mathrm{~s}, 3 \mathrm{H}), 1.32(\mathrm{~s}, 3 \mathrm{H}) ;{ }^{13} \mathrm{C} \mathrm{NMR} \delta 150.1,133.0$, 129.3, 120.6, 119.5, 119.2, 69.4, 56.9, 48.0, 22.6, 16.9; MS (EI) $m / z 177\left(\mathrm{M}^{+}, 14\right), 146$ (100), 131 (35); HRMS (EI) $m / z$ calcd for $\mathrm{C}_{11} \mathrm{H}_{15} \mathrm{NO} 177.1153$, found 177.1154.

Benzyl 4-methoxyphenylcarbamate. ${ }^{22}$ According to General Protocol D, $4.08 \mathrm{~g}(33.1 \mathrm{mmol})$ of p-anisidine, $3.06 \mathrm{~g}(36.4 \mathrm{mmol})$ of $\mathrm{NaHCO}_{3}$, and $5.2 \mathrm{~mL}(36.4 \mathrm{mmol})$ of benzyl chloroformate (reaction time $30 \mathrm{~min}$ ) provided a solid that was recrystallized (chloroform/hexane; 1:10) to 
afford $7.65 \mathrm{~g}$ (29.7 mmol, 90\%) of benzyl 4-methoxyphenylcarbamate as a pink solid: Mp $98{ }^{\circ} \mathrm{C}$; IR (KBr) 3299, 3042, 2842, 1701, 1532, 1415, 1238, 1065, 1029, 825, $743 \mathrm{~cm}^{-1} ;{ }^{1} \mathrm{H}$ NMR $\delta$ 7.42-7.24 (m, $7 \mathrm{H}), 6.86-6.81(\mathrm{~m}, 2 \mathrm{H}), 6.59$ (bs, $1 \mathrm{H}), 5.17$ (s, $2 \mathrm{H}), 3.77$ (s, $3 \mathrm{H}) ;{ }^{13} \mathrm{C}$ NMR $\delta$ $156.3,153.9,136.4,131.0,128.8,128.5,121.0,114.5,67.1,55.7$; MS (EI) $m / z 257\left(\mathrm{M}^{+}, 11\right)$, 213 (7), 122 (32), 91 (100), 65 (50); HRMS (EI) $m / z$ calcd for $\mathrm{C}_{15} \mathrm{H}_{15} \mathrm{NO}_{3}$ 257.1051, found 257.1047.

Benzyl 4-methoxyphenyl((2-methyloxiran-2-yl)methyl)carbamate (8c). According to General Protocol E, $4.21 \mathrm{~g}(16.3 \mathrm{mmol})$ of benzyl 4-methoxyphenylcarbamate, $1.30 \mathrm{~g}(32.7 \mathrm{mmol})$ of $\mathrm{NaH}$ (60\% dispersion in mineral oil), $2.5 \mathrm{~mL}$ (24.5 mmol) of 3-bromo-2-methylpropene, and $6.04 \mathrm{~g}(24.5 \mathrm{mmol})$ of $m$-CPBA $(70 \%)$ provided an oil that was purified by chromatography on $\mathrm{SiO}_{2}$ (hexanes:EtOAc; 4:1) to afford $4.34 \mathrm{~g}$ (13.2 mmol, 81\%, 2 steps) of $8 \mathbf{c}$ as an oil: IR (neat) 3520, 3037, 2935, 2837, 1701, 1609, 1585, 1512, 1444, 1428, $1294 \mathrm{~cm}^{-1}$; ${ }^{1} \mathrm{H}$ NMR $\delta$ 7.32-7.12 (m, $7 \mathrm{H}), 6.83$ (d, $2 \mathrm{H}, J=12.3 \mathrm{~Hz}), 5.12(\mathrm{bs}, 2 \mathrm{H}), 3.89,3.65$ (AB, $2 \mathrm{H}, J=14.7 \mathrm{~Hz}), 3.74$ (s, 3 $\mathrm{H}), 2.47,2.45(\mathrm{AB}, 2 \mathrm{H}, J=4.3 \mathrm{~Hz}), 1.34(\mathrm{~s}, 3 \mathrm{H}) ;{ }^{13} \mathrm{C}$ NMR $\delta 158.2,155.9,136.6,135.0,128.4$, 127.9, 127.5, 114.2, 67.4, 55.8, 55.6, 55.4, 52.4, 19.3; MS (EI) $\mathrm{m} / \mathrm{z} 327\left(\mathrm{M}^{+}, 23\right), 192(15), 146$ (23), 91 (81), 84 (100); HRMS (EI) $m / z$ calcd for $\mathrm{C}_{19} \mathrm{H}_{21} \mathrm{NO}_{4} 327.1470$, found 327.1471.

(5-Methoxy-3-methylindolin-3-yl)methanol (9c). According to General Protocol F, $236 \mathrm{mg}$ $(0.72 \mathrm{mmol})$ of $\mathbf{8 c}, 7.1 \mathrm{mg}(0.02 \mathrm{mmol})$ of $\mathrm{Cp}_{2} \mathrm{TiCl}_{2}, 170 \mathrm{mg}(1.08 \mathrm{mmol})$ of collidine hydrochloride, and $59 \mathrm{mg}(1.08 \mathrm{mmol})$ of Mn powder afforded an oil (reaction time $3 \mathrm{~h}$ ) that was subjected to $46 \mathrm{mg}(20 \% \mathrm{w} / \mathrm{w}, 0.02 \mathrm{mmol})$ of $\mathrm{Pd} / \mathrm{C}$ and $1 \mathrm{~atm}$ of $\mathrm{H}_{2}$ to provide an oil that was purified by chromatography on $\mathrm{SiO}_{2}$ (hexanes:EtOAc; 1:1) to afford $28 \mathrm{mg}(0.14 \mathrm{mmol}, 21 \%, 2$ steps) of $\mathbf{9 c}$ as a purple oil: IR (neat) 3339, 2920, 2866, 1596, 1490,1434, 1280, $1022 \mathrm{~cm}^{-1} ;{ }^{1} \mathrm{H}$ NMR $\delta$ 6.68-6.57 (m, $3 \mathrm{H}), 3.74(\mathrm{~s}, 3 \mathrm{H}), 3.61,3.54(\mathrm{AB}, 2 \mathrm{H}, J=10.8 \mathrm{~Hz}), 3.55,3.25(\mathrm{AB}, 2 \mathrm{H}$, $J=9.3 \mathrm{~Hz}), 2.64(\mathrm{bs}, 2 \mathrm{H}), 1.31(\mathrm{~s}, 3 \mathrm{H}) ;{ }^{13} \mathrm{C}$ NMR $\delta 154.0,145.3,135.8,113.1,110.9,110.2$, 69.3, 57.6, 56.2, 48.2, 22.2; MS (EI) $m / z 193\left(\mathrm{M}^{+}, 35\right), 162$ (100), 147 (42), 118 (18); HRMS (EI) $m / z$ calcd for $\mathrm{C}_{11} \mathrm{H}_{15} \mathrm{NO}_{2}$ 193.1102, found 193.1103 .

Methyl 4-(benzyloxycarbonylamino)benzoate. According to General Protocol D, $3.80 \mathrm{~g}$ (25.1 $\mathrm{mmol})$ of methyl 4-aminobenzoate, $2.32 \mathrm{~g}(27.6 \mathrm{mmol})$ of $\mathrm{NaHCO}_{3}$, and $3.9 \mathrm{~mL}(27.6 \mathrm{mmol})$ of benzyl chloroformate (reaction time $1 \mathrm{~h}$ ) provided a solid that was recrystallized (chloroform/hexane; 1:10) to afford $6.47 \mathrm{~g} \quad(22.6 \mathrm{mmol}$, 90\%) of methyl 4(benzyloxycarbonylamino)benzoate as a white solid: Mp 137-139 ${ }^{\circ} \mathrm{C}$; IR (KBr) 3311, 3117, 2956, 1729, 1694, 1602, 1537, 1451, 1323, 1221, $1042 \mathrm{~cm}^{-1} ;{ }^{1} \mathrm{H}$ NMR $\delta 7.98(\mathrm{~d}, 2 \mathrm{H}, J=8.7$ $\mathrm{Hz}), 7.45$ (d, $2 \mathrm{H}, J=8.7 \mathrm{~Hz}), 7.42-7.31(\mathrm{~m}, 5 \mathrm{H}), 6.99(\mathrm{bs}, 1 \mathrm{H}), 5.20(\mathrm{~s}, 2 \mathrm{H}), 3.88(\mathrm{~s}, 3 \mathrm{H})$;

${ }^{13} \mathrm{C}$ NMR $\delta 166.9,153.1,142.3,135.9,131.1,128.9,128.7,128.6,125.1,117.8,67.5,52.2$; MS (EI) $\mathrm{m} / z 285\left(\mathrm{M}^{+}, 38\right), 241$ (43), 177 (77), 146 (88), 91 (100); HRMS (EI) $\mathrm{m} / \mathrm{z}$ calcd for $\mathrm{C}_{16} \mathrm{H}_{15} \mathrm{NO}_{4}$ 285.1001, found 285.0999.

Methyl 4-((benzyloxycarbonyl)((2-methyloxiran-2-yl)methyl)amino)benzoate (8d). To a solution of $1.96 \mathrm{~g}(6.87 \mathrm{mmol})$ of methyl 4-(benzyloxycarbonylamino)benzoate in $20 \mathrm{~mL}$ of DMF at rt was added $190 \mathrm{mg}(7.55 \mathrm{mmol})$ of $\mathrm{NaH}$ (95\% dispersion in mineral oil). The reaction mixture was stirred until $\mathrm{H}_{2}$ evolution ceased, then $900 \mu \mathrm{L}(8.93 \mathrm{mmol})$ of 3-bromo-2- 
methylpropene was added. The mixture was stirred overnight at $\mathrm{rt}$, quenched with $\mathrm{H}_{2} \mathrm{O}$, poured onto ice and extracted with $3 \times 20 \mathrm{~mL}$ of dichloromethane. The combined organic layers were washed with $50 \mathrm{~mL}$ of $\mathrm{H}_{2} \mathrm{O}$, dried $\left(\mathrm{MgSO}_{4}\right)$ and concentrated in vacuo. The crude residue was dissolved in $60 \mathrm{~mL}$ of dichloromethane, cooled to $0{ }^{0} \mathrm{C}$ and treated batchwise with $2.03 \mathrm{~g}(8.24$ mmol) of $m$-CPBA (70\%). The disappearance of starting material was monitored by TLC (hexanes:EtOAc; 2:1). The reaction mixture was quenched with aq. $\mathrm{Na}_{2} \mathrm{~S}_{2} \mathrm{O}_{3}$ solution and extracted with $3 \times 15 \mathrm{~mL}$ of dichloromethane. The combined organic layers were dried $\left(\mathrm{MgSO}_{4}\right)$, concentrated in vacuo and purified by chromatography on $\mathrm{SiO}_{2}$ (hexanes:EtOAc; 5:1 to 3:1) to afford $2.06 \mathrm{~g}$ (5.79 mmol, 84\%, 2 steps) of $\mathbf{8 d}$ as an oil: IR (neat) 3522, 3033, 2952, 1709, 1605, 1436, 1279, 1109, 1015, $773 \mathrm{~cm}^{-1} ;{ }^{1} \mathrm{H}$ NMR $\delta 8.01(\mathrm{~d}, 2 \mathrm{H}, J=8.7 \mathrm{~Hz}), 7.37-7.25$ (m, $\left.7 \mathrm{H}\right), 5.17$ $(\mathrm{s}, 2 \mathrm{H}), 3.92,3.85(\mathrm{AB}, 2 \mathrm{H}, J=14.8 \mathrm{~Hz}), 3.89$ (s, $3 \mathrm{H}), 2.51$ (appt. s, $2 \mathrm{H}), 1.34$ (s, $3 \mathrm{H}) ;{ }^{13} \mathrm{C}$ NMR $\delta 166.5,155.2,146.5,136.1,130.5,128.6,128.3,128.2,128.0,126.6,68.0,55.9,55.0$, 52.3, 52.2, 19.4; MS (EI) m/z 355 (M+, 62), 324 (30), 254 (55), 132 (49), 91 (100); HRMS (EI) $\mathrm{m} / z$ calcd for $\mathrm{C}_{20} \mathrm{H}_{21} \mathrm{NO}_{5} 355.1419$, found 355.1415 .

Methyl 3-(hydroxymethyl)-3-methylindoline-5-carboxylate (9d). According to General Protocol F, $206 \mathrm{mg}(0.57 \mathrm{mmol})$ of $\mathbf{8 d}, 4.3 \mathrm{mg}(0.01 \mathrm{mmol})$ of $\mathrm{Cp}_{2} \mathrm{TiCl}_{2}, 136 \mathrm{mg}(0.86 \mathrm{mmol})$ of collidine hydrochloride, and $47 \mathrm{mg}(0.86 \mathrm{mmol})$ of Mn powder (reaction time $5 \mathrm{~h}$ ) provided an intermediate that was purified by chromatography on $\mathrm{SiO}_{2}$ (hexanes:EtOAc; 5:1). The oily intermediate was subjected to $20 \mathrm{mg}(10 \% \mathrm{w} / \mathrm{w}, 9.3 \mu \mathrm{mol})$ of $\mathrm{Pd} / \mathrm{C}$ and $1 \mathrm{~atm}$ of $\mathrm{H}_{2}$, and the reaction mixture was purified by chromatography on $\mathrm{SiO}_{2}$ (hexanes:EtOAc; 1:1 with 1\% $\mathrm{NEt}_{3}$ ) to afford $72 \mathrm{mg}(0.32 \mathrm{mmol}, 56 \%, 2$ steps) of 9d as an oil: IR (neat) 3368, 2952, 2868, 1687, 1610, 1502, 1293, 1253, $1110 \mathrm{~cm}^{-1}$; ${ }^{1} \mathrm{H}$ NMR $\delta 7.78(\mathrm{dd}, 1 \mathrm{H}, J=8.4,1.8 \mathrm{~Hz}), 7.68(\mathrm{~d}, 1 \mathrm{H}, J=$ $1.8 \mathrm{~Hz}), 6.53(\mathrm{~d}, 1 \mathrm{H}, J=8.4 \mathrm{~Hz}), 4.21(\mathrm{bs}, 1 \mathrm{H}), 3.83$ (s, $3 \mathrm{H}), 3.69$ (d, $1 \mathrm{H}, J=9.1 \mathrm{~Hz}), 3.64$, $3.54(\mathrm{AB}, 2 \mathrm{H}, J=10.8 \mathrm{~Hz}), 3.34(\mathrm{~d}, 1 \mathrm{H}, J=9.1 \mathrm{~Hz}), 2.02(\mathrm{bs}, 1 \mathrm{H}), 1.33(\mathrm{~s}, 3 \mathrm{H}) ;{ }^{13} \mathrm{C}$ NMR $\delta$ 167.6, 155.8, 133.2, 131.7, 124.9, 119.6, 107.8, 69.1, 57.0, 51.8, 47.1, 22.8; MS (EI) $\mathrm{m} / z 221$ $\left(\mathrm{M}^{+}, 23\right), 190$ (81), 158 (100), 130 (68); HRMS (EI) $\mathrm{m} / z$ calcd for $\mathrm{C}_{12} \mathrm{H}_{15} \mathrm{NO}_{3} 221.1051$, found 221.1053.

Benzyl 4-chlorophenylcarbamate. According to General Protocol D, $3.81 \mathrm{~g}(29.8 \mathrm{mmol})$ of $p$ chloroaniline, $2.57 \mathrm{~g}(32.8 \mathrm{mmol})$ of $\mathrm{NaHCO}_{3}$, and $4.6 \mathrm{~mL}(32.8 \mathrm{mmol})$ of benzyl chloroformate provided a solid that was recrystallized (chloroform:hexanes; $1: 10)$ to afford $6.57 \mathrm{~g}(25.1 \mathrm{mmol}$, $84 \%$ ) of benzyl 4-chlorophenylcarbamate as pink needles: Mp 109-111 ${ }^{\circ} \mathrm{C}$; IR (KBr) 3320 , $3112,3037,2954,1707,1594,1528,1403,1237,1065,822,737 \mathrm{~cm}^{-1} ;{ }^{1} \mathrm{H}$ NMR $\delta 7.41-7.23(\mathrm{~m}$, $9 \mathrm{H}), 6.70(\mathrm{bs}, 1 \mathrm{H}), 5.18(\mathrm{~s}, 2 \mathrm{H}) ;{ }^{13} \mathrm{C} \mathrm{NMR} \delta 153.4,136.6,136.0,129.3,128.9,128.8,128.7$, 128.5, 120.1, 67.4; MS (EI) m/z $261\left(\mathrm{M}^{+}, 20\right), 217$ (15), 153 (79), 91 (100); HRMS (EI) $\mathrm{m} / z$ calcd for $\mathrm{C}_{14} \mathrm{H}_{12} \mathrm{ClNO}_{2} 261.0556$, found 261.0561.

Benzyl 4-chlorophenyl((2-methyloxiran-2-yl)methyl)carbamate (8e). According to General

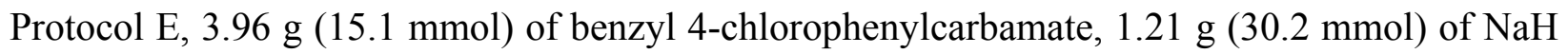
(60\% dispersion in mineral oil), $2.3 \mathrm{~mL}$ (22.6 mmol) of 3-bromo-2-methylpropene, and $5.58 \mathrm{~g}$ (22.6 mmol) of $m$-CPBA (70\%) provided an oil that was purified by chromatography on $\mathrm{SiO}_{2}$ (hexanes:EtOAc; 4:1) to afford $3.96 \mathrm{~g}$ (11.9 mmol, 79\%, 2 steps) of 8e as an orange solid: Mp 
58-60 ${ }^{\circ} \mathrm{C}$; IR (KBr) 3319, 3400, 3036, 2968, 2279, 1702, 1412, 1263, 1148, 1090, 1011, 837, 734 $\mathrm{cm}^{-1}$; ${ }^{1} \mathrm{H}$ NMR $\delta$ 7.32-7.16 (m, $\left.9 \mathrm{H}\right), 5.14$ (s, $\left.2 \mathrm{H}\right), 3.86,3.75(\mathrm{AB}, 2 \mathrm{H}, J=14.8 \mathrm{~Hz}), 2.51,2.50$ $(\mathrm{AB}, 2 \mathrm{H}, J=4.9 \mathrm{~Hz}), 1.34$ (s, $3 \mathrm{H}) ;{ }^{13} \mathrm{C} \mathrm{NMR} \delta 155.5,140.9,136.3,132.5,129.2,128.6,128.5$, 128.3, 127.9, 67.8, 55.8, 55.4, 52.3, 19.4; MS (EI) m/z $331\left(\mathrm{M}^{+}, 33\right), 230$ (46), 111 (42), 91 (100), 84 (94); HRMS (EI) $m / z$ calcd for $\mathrm{C}_{18} \mathrm{H}_{18} \mathrm{ClNO}_{3} 331.0975$, found 331.0975 .

Benzyl 5-chloro-3-(hydroxymethyl)-3-methylindoline-1-carboxylate (9e). According to General Protocol C, $318 \mathrm{mg}(0.95 \mathrm{mmol})$ of 8e, $7.1 \mathrm{mg}(0.02 \mathrm{mmol})$ of $\mathrm{Cp}_{2} \mathrm{TiCl}_{2}, 226 \mathrm{mg}(1.43$ $\mathrm{mmol}$ ) of collidine hydrochloride, and $79 \mathrm{mg}$ (1.43 mmol) of Mn powder (reaction time $4 \mathrm{~h}$ ) provided a mixture that was purified by chromatography on $\mathrm{SiO}_{2}$ (hexanes:EtOAc; $5: 1$ to 3:1) to afford $130 \mathrm{mg}(0.39 \mathrm{mmol}, 41 \%)$ of $9 \mathrm{e}$ as an oil: IR (neat) 3435, 2959, 1706, 1597, 1485, 1401, 1334, $1075 \mathrm{~cm}^{-1} ;{ }^{1} \mathrm{H}$ NMR (DMSO- $\left.d_{6}, 350 \mathrm{~K}\right) \delta 7.64(\mathrm{~d}, 1 \mathrm{H}, J=8.4 \mathrm{~Hz}), 7.46-7.29$ (m, $5 \mathrm{H}$ ), $7.23(\mathrm{~d}, 1 \mathrm{H}, J=2.1 \mathrm{~Hz}), 7.19(\mathrm{dd}, 1 \mathrm{H}, J=8.7,2.4 \mathrm{~Hz}), 5.24(\mathrm{~s}, 2 \mathrm{H}), 4.71$ (bs, $1 \mathrm{H}), 4.06$ (d, 1 $\mathrm{H}, J=11.1 \mathrm{~Hz}), 3.64(\mathrm{~d}, 1 \mathrm{H}, J=11.1 \mathrm{~Hz}), 3.45,3.42(\mathrm{AB}, 2 \mathrm{H}, J=10.5 \mathrm{~Hz}), 1.27(\mathrm{~s}, 3 \mathrm{H}) ;{ }^{13} \mathrm{C}$ NMR (DMSO- $\left.d_{6}, 350 \mathrm{~K}\right) \delta 151.9,140.5,139.5,136.0,127.9,127.5,127.2,126.9,126.0,123.1$, 114.7, 67.3, 66.3, 57.2, 44.7, 22.6; MS (EI) m/z $331\left(\mathrm{M}^{+}, 40\right), 256$ (14), 91 (100); HRMS (ESI) $m / z$ calcd for $\mathrm{C}_{18} \mathrm{H}_{18} \mathrm{ClNO}_{3} \mathrm{Na}(\mathrm{M}+\mathrm{Na}) 354.0873$, found 354.0851 .

3-(tert-Butyldimethylsilyloxy)aniline. To a solution of $5.78 \mathrm{~g}(53.0 \mathrm{mmol})$ of 3-aminophenol (10) in $200 \mathrm{~mL}$ of THF was added $5.77 \mathrm{~g}(84.8 \mathrm{mmol})$ of imidazole, followed by $10.38 \mathrm{~g}(68.86$ $\mathrm{mmol}$ ) of TBSCl. The reaction mixture was stirred at rt overnight, quenched with $50 \mathrm{~mL}$ of satd. $\mathrm{NH}_{4} \mathrm{Cl}$, extracted with $3 \times 50 \mathrm{~mL}$ of $\mathrm{Et}_{2} \mathrm{O}$, washed with brine, dried $\left(\mathrm{MgSO}_{4}\right)$, concentrated, and purified on $\mathrm{SiO}_{2}$ (hexanes:EtOAc; 15:1 to 5:1 gradient) to afford $11.06 \mathrm{~g}(49.50 \mathrm{mmol}, 93 \%)$ of 3-(tert-butyldimethylsilyloxy)aniline as a tan oil: ${ }^{1} \mathrm{H} \mathrm{NMR}(600 \mathrm{MHz}) \delta 6.99(\mathrm{t}, 1 \mathrm{H}, J=8.4 \mathrm{~Hz})$, 6.30 (dd, $1 \mathrm{H}, J=7.8 \mathrm{~Hz}, 1.8 \mathrm{~Hz}$ ), 6.25 (dd, $1 \mathrm{H}, J=7.8 \mathrm{~Hz}, 1.8 \mathrm{~Hz}$ ), 6.20 (app t, $1 \mathrm{H}, J=1.8$ $\mathrm{Hz}), 3.62$ (br s, $2 \mathrm{H}), 0.97$ (s, $9 \mathrm{H}), 0.19$ (s, $6 \mathrm{H}) ;{ }^{13} \mathrm{C}$ NMR $(150 \mathrm{MHz}) \delta 156.9,147.8,130.1$, 110.7, 108.7, 107.4, 25.9, 18.4, -4.2).

Ethyl 3-(tert-butyldimethylsilyloxy)phenylcarbamate (11). To a solution of $6.51 \mathrm{~g}$ (29.1 mmol) of 3-(tert-butyldimethylsilyloxy)aniline in $150 \mathrm{~mL}$ of dichloromethane cooled to $0{ }^{\circ} \mathrm{C}$ was added $3.9 \mathrm{~mL}$ of pyridine, followed by $2.9 \mathrm{~mL}(31 \mathrm{mmol})$ of ethylchloroformate dropwise over 1 $\mathrm{h}$. The reaction mixture was allowed to warm to $\mathrm{rt}$, stirred for $1 \mathrm{~h}$, and then quenched with $60 \mathrm{~mL}$ of satd. $\mathrm{NH}_{4} \mathrm{Cl}$, diluted with $60 \mathrm{~mL}$ of $\mathrm{H}_{2} \mathrm{O}$, extracted with $2 \times 20 \mathrm{~mL}$ of dichloromethane, dried $\left(\mathrm{MgSO}_{4}\right)$, concentrated, and purified on $\mathrm{SiO}_{2}$ (hexanes:EtOAc; 10:1) to afford $8.34 \mathrm{~g}(28.22$ mmol, 97\%) of 11 as a golden oil: IR (ATR) 3321, 2957, 2930, 2859, 1704, 1596, 1540, 1220, $1063 \mathrm{~cm}^{-1} ;{ }^{1} \mathrm{H}$ NMR $(600 \mathrm{MHz}) \delta 7.12(\mathrm{t}, 1 \mathrm{H}, J=7.8 \mathrm{~Hz}), 7.04$ (br s, $\left.1 \mathrm{H}\right), 6.88$ (br d, $1 \mathrm{H}, J=$ $7.8 \mathrm{~Hz}), 6.67$ (br s, $1 \mathrm{H}), 6.54$ (dd, $1 \mathrm{H}, J=8.1 \mathrm{~Hz}, 2.4 \mathrm{~Hz}), 4.21$ (q, $2 \mathrm{H}, J=6.6 \mathrm{~Hz}), 1.29$ (t, 3 $\mathrm{H}, J=7.2 \mathrm{~Hz}), 0.97(\mathrm{~s}, 9 \mathrm{H}), 0.20(\mathrm{~s}, 6 \mathrm{H}) ;{ }^{13} \mathrm{C}$ NMR $(150 \mathrm{MHz}) \delta 156.5,153.7,139.3,129.8$, 115.2, 111.7, 110.8, 61.3, 25.9, 18.4, 14.7, -4.3; MS (ESI) $m / z 318\left([\mathrm{M}+\mathrm{Na}]^{+}\right)$.

Ethyl 3-(tert-butyldimethylsilyloxy)phenyl(2-methylallyl)carbamate. To a solution of $6.09 \mathrm{~g}$ (20.6 mmol) of 11 in $100 \mathrm{~mL}$ of distilled THF cooled to $0{ }^{\circ} \mathrm{C}$ was added $380 \mathrm{mg}(1.03 \mathrm{mmol})$ of TBAI, followed by $937 \mathrm{mg}(37.1 \mathrm{mmol})$ of $\mathrm{NaH} \mathrm{95 \%} \mathrm{(added} \mathrm{piecewise).} \mathrm{The} \mathrm{reaction} \mathrm{mixture}$ was stirred at $0{ }^{\circ} \mathrm{C}$ for $20 \mathrm{~min}$ when $3.1 \mathrm{~mL}(31 \mathrm{mmol})$ of methallyl bromide was added. Upon 
addition of the methallyl bromide, the flask was removed from the ice bath and the mixture was stirred for a total of $3 \mathrm{~h}$ when TLC (hexanes:EtOAc; $4: 1$ ) analysis showed the starting material was consumed. The mixture was then cooled to $0{ }^{\circ} \mathrm{C}$, quenched with $10 \mathrm{~mL}$ of $\mathrm{H}_{2} \mathrm{O}$, extracted with $3 \times 10 \mathrm{~mL}$ of $\mathrm{Et}_{2} \mathrm{O}$, washed with $10 \mathrm{~mL}$ of brine, dried $\left(\mathrm{Na}_{2} \mathrm{SO}_{4}\right)$, concentrated and purified on $\mathrm{SiO}_{2}$ (hexanes:EtOAc; 12:1) to afford $4.96 \mathrm{~g}$ (14.19 mmol, 69\%) of ethyl 3-(tertbutyldimethylsilyloxy)phenyl(2-methylallyl)carbamate as a tan oil: IR (ATR) 2931, 1703, 1597, 1488, 1252, $1193 \mathrm{~cm}^{-1}$; ${ }^{1} \mathrm{H}$ NMR (600 MHz, DMSO-d $) \delta 7.20(\mathrm{t}, 1 \mathrm{H}, J=7.8 \mathrm{~Hz}), 6.88(\mathrm{dd}, 1$ $\mathrm{H}, J=7.8 \mathrm{~Hz}, J=1.2 \mathrm{~Hz}), 6.74(\mathrm{~s}, 1 \mathrm{H}), 6.68(\mathrm{dd}, 1 \mathrm{H}, J=7.8 \mathrm{~Hz}, J=1.8 \mathrm{~Hz}), 4.79(\mathrm{~s}, 1 \mathrm{H})$, $4.70(\mathrm{~s}, 1 \mathrm{H}), 4.18(\mathrm{~s}, 1 \mathrm{H}), 4.07$ (q, $2 \mathrm{H}, J=7.2 \mathrm{~Hz}), 1.66(\mathrm{~s}, 3 \mathrm{H}), 1.14(\mathrm{t}, 3 \mathrm{H}, J=6.6 \mathrm{~Hz}), 0.93$ $(\mathrm{s}, 9 \mathrm{H}), 0.17(\mathrm{~s}, 6 \mathrm{H}) ;{ }^{13} \mathrm{C}$ NMR $\left(150 \mathrm{MHz}, \mathrm{DMSO}-d_{6}\right) \delta 155.0,154.6,142.8,141.2,129.3$, 119.0, 118.0, 117.4, 111.6, 61.2, 55.0, 25.5, 19.8, 18.0, 14.4, -4.6; MS (ESI) $m / z 372\left([\mathrm{M}+\mathrm{Na}]^{+}\right)$.

Ethyl 3-(tert-butyldimethylsilyloxy)phenyl((2-methyloxiran-2-yl)methyl)carbamate (12). To a $0{ }^{\circ} \mathrm{C}$ solution of $388 \mathrm{mg}(1.11 \mathrm{mmol})$ of ethyl 3-(tert-butyldimethylsilyloxy)phenyl(2methylallyl)carbamate in $5 \mathrm{~mL}$ of dichloromethane and $235 \mathrm{mg}(2.22 \mathrm{mmol})$ of $\mathrm{Na}_{2} \mathrm{CO}_{3}$ in $2 \mathrm{~mL}$ of water was added $410 \mathrm{mg}$ (1.67 mmol) of $m$-CPBA (70\% purity). The mixture was allowed to warm from $0{ }^{\circ} \mathrm{C}$ to $10{ }^{\circ} \mathrm{C}$ over $2 \mathrm{~h}$ when the flask was removed from the cold bath and allowed to warm to $23{ }^{\circ} \mathrm{C}$. At this time, an additional $273 \mathrm{mg}$ of $m$-CPBA was added. After $30 \mathrm{~min}$, the reaction was determined to be complete by TLC analysis (hexanes:EtOAc; 2:1) and was quenched with $15 \mathrm{~mL}$ of $\mathrm{Na}_{2} \mathrm{~S}_{2} \mathrm{O}_{3}$ solution, extracted with $3 \times 10 \mathrm{~mL}$ of $\mathrm{CHCl}_{3}$, dried $\left(\mathrm{MgSO}_{4}\right)$, concentrated, and purified on $\mathrm{SiO}_{2}$ (hexanes:EtOAc; 10:1 to 6:1 gradient) to afford $236 \mathrm{mg}(0.65$ mmol, 58\%) of 12 as a light yellow oil: IR (ATR) 2931, 2859, 1703, 1597, 1488, 1260, $954 \mathrm{~cm}^{-1}$; ${ }^{1} \mathrm{H}$ NMR $(600 \mathrm{MHz}) \delta 7.19(\mathrm{t}, 1 \mathrm{H}, J=7.8 \mathrm{~Hz}), 6.84(\mathrm{~d}, 1 \mathrm{H}, J=7.8 \mathrm{~Hz}), 6.74-6.72(\mathrm{~m}, 2 \mathrm{H})$, 4.16 (q, $2 \mathrm{H}, J=7.2 \mathrm{~Hz}), 3.99(\mathrm{~d}, 1 \mathrm{H}, J=14.4 \mathrm{~Hz}), 3.61$ (d, $1 \mathrm{H}, J=14.4 \mathrm{~Hz}), 2.54$ (A of AB, 1 $\mathrm{H}, J=4.8 \mathrm{~Hz}$ ), 2.52 (B of AB, $1 \mathrm{H}, J=4.8 \mathrm{~Hz}), 1.38(\mathrm{~s}, 3 \mathrm{H}), 1.21(\mathrm{bs}, 3 \mathrm{H}), 0.98(\mathrm{~s}, 9 \mathrm{H}), 0.20$ $(\mathrm{s}, 6 \mathrm{H}) ;{ }^{13} \mathrm{C} \mathrm{NMR}(150 \mathrm{MHz}) \delta 156.2,156.0,143.5,129.6,120.0,119.5,118.8,62.1,55.9,55.6$, 53.0, 25.9, 19.6, 18.4, 14.8, -4.2; MS (EI) $m / z 365$ (M , 77), 280 (55), 238 (67), 220 (100), 192 (97), 178 (65); HRMS (EI) $m / z$ calcd for $\mathrm{C}_{19} \mathrm{H}_{31} \mathrm{NO}_{4} \mathrm{Si} 365.2022$, found 365.2033.

(6-(tert-Butyldimethylsilyloxy)-1,3-dimethylindolin-3-yl)methanol (15). A mixture of $178 \mathrm{mg}$ $(0.486 \mathrm{mmol})$ of $12,115 \mathrm{mg}(0.730 \mathrm{mmol})$ of coll-HCl, $40 \mathrm{mg}(0.73 \mathrm{mmol})$ of $\mathrm{Mn}$ powder, and $3.6 \mathrm{mg}(0.015 \mathrm{mmol})$ of $\mathrm{Cp}_{2} \mathrm{TiCl}_{2}$ was purged with argon 3 times, dissolved in $5.0 \mathrm{~mL}$ of distilled, degassed THF, and heated at reflux. After $4 \mathrm{~h}$, the solution was allowed to cool to room temperature and was quenched with $10 \mathrm{~mL}$ of satd. $\mathrm{NH}_{4} \mathrm{Cl}$, extracted with $3 \times 10 \mathrm{~mL}$ of EtOAc, washed with $10 \mathrm{~mL}$ of brine, dried $\left(\mathrm{Na}_{2} \mathrm{SO}_{4}\right)$, concentrated, and purified on neutral alumina (hexanes:EtOAc; $10: 1$ to $1: 1$ gradient) to afford $53 \mathrm{mg}(0.14 \mathrm{mmol}, 30 \%)$ of 13 . To a solution of $53 \mathrm{mg}(0.14 \mathrm{mmol})$ of $13 \mathrm{in} 3 \mathrm{~mL}$ of dry THF cooled to $0{ }^{\circ} \mathrm{C}$ was added $28 \mathrm{mg}(0.72 \mathrm{mmol})$ of $\mathrm{LiAlH}_{4}$. Upon addition, the mixture was stirred until no gas evolution was observed and then heated at reflux. TLC analysis (hexanes:EtOAc; 1:1) after 50 min showed that the starting material was consumed. The solution was cooled to $0{ }^{\circ} \mathrm{C}$, quenched with $\mathrm{MeOH}$, diluted with 5 $\mathrm{mL}$ of $\mathrm{H}_{2} \mathrm{O}$, saturated with potassium sodium tartrate, and diluted with $5 \mathrm{~mL}$ of EtOAc. The solution was stirred until biphasic when it was partitioned and extracted with 3 x $5 \mathrm{~mL}$ of EtOAc. 
The combined organic extracts were washed with $5 \mathrm{~mL}$ of brine, dried $\left(\mathrm{Na}_{2} \mathrm{SO}_{4}\right)$, concentrated, and purified by chromatography on $\mathrm{SiO}_{2}$ (hexanes:EtOAc; $\left.2: 1\right)$ to afford $38 \mathrm{mg}(0.12 \mathrm{mmol}$, $85 \%$ ) of 15 as a colorless oil: IR (ATR) 3373, 2956, 1612, 1497, 1253, $985 \mathrm{~cm}^{-1} ;{ }^{1} \mathrm{H}$ NMR (600 $\mathrm{MHz}) \delta 6.81(\mathrm{~d}, 1 \mathrm{H}, J=7.8 \mathrm{~Hz}), 6.15(\mathrm{dd}, 1 \mathrm{H}, J=7.8 \mathrm{~Hz}, 1.8 \mathrm{~Hz}), 5.98(\mathrm{~d}, 1 \mathrm{H}, J=1.8 \mathrm{~Hz})$, 3.56 (A of AB, $1 \mathrm{H}, J=10.8 \mathrm{~Hz}$ ), 3.51 (B of AB, $1 \mathrm{H}, J=10.8 \mathrm{~Hz}), 3.40(\mathrm{~d}, 1 \mathrm{H}, J=9.0 \mathrm{~Hz}$ ), $2.98(\mathrm{~d}, 1 \mathrm{H}, J=9.0 \mathrm{~Hz}), 2.70(\mathrm{~s}, 3 \mathrm{H}), 1.65(\mathrm{bs}, 1 \mathrm{H}), 1.28(\mathrm{~s}, 3 \mathrm{H}), 0.98(\mathrm{~s}, 9 \mathrm{H}), 0.19(\mathrm{~s}, 6 \mathrm{H})$; ${ }^{13} \mathrm{C}$ NMR $(150 \mathrm{MHz}) \delta 156.8,154.6,127.1,122.8,108.8,100.4,69.4,66.0,45.7,35.9,25.9$, 22.3, 18.4, -4.2; MS (EI) m/z $307\left(\mathrm{M}^{+}, 40\right), 276$ (100), 204 (20), 73 (24); HRMS (EI) $\mathrm{m} / z$ calcd for $\mathrm{C}_{17} \mathrm{H}_{29} \mathrm{NO}_{2} \mathrm{Si} 307.1968$, found 307.1960.

3-(Hydroxymethyl)-1,3-dimethylindolin-4-ol (16). A mixture of $178 \mathrm{mg}(0.486 \mathrm{mmol})$ of 12, $115 \mathrm{mg}(0.730 \mathrm{mmol})$ of coll-HCl, $40 \mathrm{mg}(0.73 \mathrm{mmol})$ of Mn powder, and $3.6 \mathrm{mg}(0.015 \mathrm{mmol})$ of $\mathrm{Cp}_{2} \mathrm{TiCl}_{2}$ was purged with argon 3 times, dissolved in $5.0 \mathrm{~mL}$ of distilled, degassed THF, and heated at reflux. After $4 \mathrm{~h}$, the reaction mixture was allowed to cool to room temperature and quenched with $10 \mathrm{~mL}$ of satd. $\mathrm{NH}_{4} \mathrm{Cl}$, extracted with $3 \times 10 \mathrm{~mL}$ of EtOAc, washed with $10 \mathrm{~mL}$ of brine, dried $\left(\mathrm{Na}_{2} \mathrm{SO}_{4}\right)$, concentrated, and purified by chromatography on neutral alumina (hexanes:EtOAc; $10: 1$ to $1: 1$ gradient) to afford $59 \mathrm{mg}(0.16 \mathrm{mmol}, 33 \%)$ of 14 . To a solution of $59 \mathrm{mg}(0.16 \mathrm{mmol})$ of $14 \mathrm{in} 3 \mathrm{~mL}$ of dry THF cooled to $0{ }^{\circ} \mathrm{C}$ was added $31 \mathrm{mg}(0.81 \mathrm{mmol})$ of $\mathrm{LiAlH}_{4}$. Upon addition and after visible gas evolution had ceased, the mixture was heated at reflux. TLC analysis (hexanes:EtOAc; 1:1) after 50 min showed that starting material was consumed. The mixture was cooled to $0{ }^{\circ} \mathrm{C}$ and then quenched dropwise with $\mathrm{MeOH}$ until no further gas evolution was observed. To this solution was added $2 \mathrm{~mL}$ of a satd. potassium sodium tartrate followed by $5 \mathrm{~mL}$ of EtOAc. The mixture was extracted with 3 x $5 \mathrm{~mL}$ of EtOAc, dried $\left(\mathrm{Na}_{2} \mathrm{SO}_{4}\right)$, concentrated and purified by chromatography on $\mathrm{SiO}_{2}$ (hexanes:EtOAc; $2: 1$ ) to afford $24 \mathrm{mg}(0.12 \mathrm{mmol}, 77 \%$, (25\% over 2 steps) of 16 as a tan waxy solid: IR (ATR) 3206, 2959, 1617, 1595, 1477, 1246, $903 \mathrm{~cm}^{-1} ;{ }^{1} \mathrm{H}$ NMR (600 MHz) $\delta 8.33$ (bs, $\left.1 \mathrm{H}\right), 7.01$ (t, $1 \mathrm{H}, J=7.8$ $\mathrm{Hz}), 6.28(\mathrm{~d}, 1 \mathrm{H}, J=8.4 \mathrm{~Hz}), 6.07(\mathrm{~d}, 1 \mathrm{H}, J=7.8 \mathrm{~Hz}), 3.90(\mathrm{~d}, 1 \mathrm{H}, J=9.6 \mathrm{~Hz}), 3.75(\mathrm{~d}, 1 \mathrm{H}, J$ $=9.6 \mathrm{~Hz}), 3.09(\mathrm{~d}, 1 \mathrm{H}, J=9.0 \mathrm{~Hz}), 2.88(\mathrm{~d}, 1 \mathrm{H}, J=8.4 \mathrm{~Hz}), 2.85(\mathrm{bs}, 1 \mathrm{H}), 2.73(\mathrm{~s}, 3 \mathrm{H}), 1.42$ (s, $3 \mathrm{H}) ;{ }^{13} \mathrm{C}$ NMR $(150 \mathrm{MHz}) \delta 154.1,153.4,129.9,119.2,107.5,100.1,70.1,65.5,46.3,36.0$, 21.5; MS (EI) m/z $193\left(\mathrm{M}^{+}, 26\right), 162$ (100), 147 (29); HRMS (EI) $m / z$ calcd for $\mathrm{C}_{11} \mathrm{H}_{15} \mathrm{NO}_{2}$ 193.1103, found 193.1100 .

1-((2-Methyloxiran-2-yl)methyl)-1,2,3,4-tetrahydroquinoline (18). To a solution of $1.48 \mathrm{~g}$ (11.1 mmol) of 1,2,3,4-tetrahydroquinoline (17) in $40 \mathrm{~mL}$ of acetonitrile was added $7.67 \mathrm{~g}(55.5$ $\mathrm{mmol})$ of $\mathrm{K}_{2} \mathrm{CO}_{3}$ and $1.6 \mathrm{~mL}(16.6 \mathrm{mmol})$ of 3-bromo-2-methylpropene at room temperature. The disappearance of starting material was monitored by TLC (hexanes:EtOAc; 4:1). The reaction was quenched with $\mathrm{H}_{2} \mathrm{O}$ and extracted with $3 \times 20 \mathrm{~mL}$ of $\mathrm{Et}_{2} \mathrm{O}$. The combined organic layers were dried $\left(\mathrm{MgSO}_{4}\right)$ and concentrated to afford a brown oil that was used without purification. According to General Protocol B, the crude reaction mixture, $1.69 \mathrm{~g}$ (14.4 mmol) of $\mathrm{NMO}$ and $370 \mu \mathrm{L}$ of $\mathrm{OsO}_{4}(1 \mathrm{~mol} \%, 0.33 \mathrm{M}$ in toluene) produced a residue which was filtered through a pad of Florisil, purified on $\mathrm{SiO}_{2}$ (hexanes:EtOAc;1:1) and concentrated in vacuo. The diol intermediate was subsequently dissolved in $89 \mathrm{~mL}$ of THF and cooled to $0{ }^{\circ} \mathrm{C}$. To this 
solution was added $564 \mathrm{mg}(22.3 \mathrm{mmol})$ of $\mathrm{NaH}(95 \%)$. The mixture was stirred for $15 \mathrm{~min}$ and $3.50 \mathrm{~g}(10.7 \mathrm{mmol})$ of $p-\mathrm{Ts}_{2} \mathrm{O}$ was added in portions. The disappearance of starting material was monitored by TLC (hexanes:EtOAc; 1:1). The reaction mixture was quenched with $\mathrm{H}_{2} \mathrm{O}$ and extracted with $3 \times 10 \mathrm{~mL}$ of EtOAc. The combined organic layers were dried $\left(\mathrm{MgSO}_{4}\right)$, concentrated in vacuo and purified by chromatography on $\mathrm{SiO}_{2}$ (hexanes:EtOAc; 8:1 with 1\% $\left.\mathrm{NEt}_{3}\right)$ to afford $1.38 \mathrm{~g}$ (6.78 mmol, 61\%, 3 steps) of $\mathbf{1 8}$ as a colorless oil: IR (ATR) 2924, 1660, 1599, 1498, 1455, $1192 \mathrm{~cm}^{-1} ;{ }^{1} \mathrm{H}$ NMR $\delta 7.11(\mathrm{t}, 1 \mathrm{H}, J=7.5 \mathrm{H}), 7.01(\mathrm{~d}, 1 \mathrm{H}, J=8.1 \mathrm{~Hz}), 6.65$ $(\mathrm{t}, 2 \mathrm{H}, J=8.1 \mathrm{~Hz}), 3.53,3.41(\mathrm{AB}, 2 \mathrm{H}, J=15.9 \mathrm{~Hz}), 3.48-3.31(\mathrm{~m}, 2 \mathrm{H}), 2.82($ app t, $2 \mathrm{H}, J=$ $6.0 \mathrm{~Hz}$ ), 2.76, $2.66(\mathrm{AB}, 2 \mathrm{H}, J=4.8 \mathrm{~Hz}), 1.99$ (app quint, $2 \mathrm{H}, J=6.0 \mathrm{~Hz}$ ), $1.44(\mathrm{~s}, 3 \mathrm{H}) ;{ }^{13} \mathrm{C}$ NMR $\delta 145.8,129.2,127.1,122.2,116.1,111.0,56.6,55.9,51.9,50.9,28.3,22.2,19.5 ;$ MS (EI) $m / z 203\left(\mathrm{M}^{+}, 44\right), 146(100), 130$ (20); HRMS (EI) $m / z$ calcd for $\mathrm{C}_{13} \mathrm{H}_{17} \mathrm{NO} 203.1310$, found 203.1320.

(1-Methyl-2,4,5,6-tetrahydro-1H-pyrrolo[3,2,1-ij]quinolin-1-yl)methyl acetate (19). According to General Protocol F, $206 \mathrm{mg}$ (1.01 mmol) of 15, $239 \mathrm{mg}$ (1.52 mmol) of collidine hydrochloride, $7.5 \mathrm{mg}(0.03 \mathrm{mmol})$ of $\mathrm{Cp}_{2} \mathrm{TiCl}_{2}$, and $111 \mathrm{mg}(2.02 \mathrm{mmol})$ of $\mathrm{Mn}$ powder afforded a crude reaction mixture that was subjected to $12 \mathrm{mg}(0.10 \mathrm{mmol})$ of DMAP and 290 $\mathrm{uL}(3.04 \mathrm{mmol})$ of acetic anhydride in $10 \mathrm{~mL}$ of THF. The mixture was stirred for $5 \mathrm{~h}$ at $\mathrm{rt}$ until TLC analysis (hexanes:EtOAc; 2:1) showed complete consumption of the alcohol. The reaction

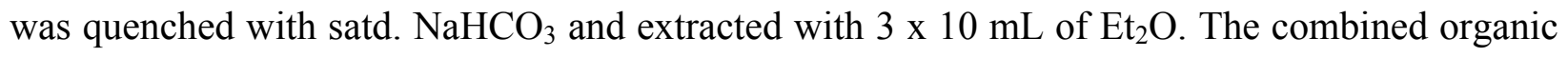
layers were dried $\left(\mathrm{MgSO}_{4}\right)$, concentrated, and purified on $\mathrm{SiO}_{2}$ (hexanes:EtOAc; 12:1) to afford $172 \mathrm{mg}$ (0.70 mmol, 69\%, 2 steps) of 19 as an oil: IR (neat) 2936, 2806, 1740, 1599, 1489, 1236, $1034 \mathrm{~cm}^{-1} ;{ }^{1} \mathrm{H}$ NMR $\delta 6.87(\mathrm{dd}, 2 \mathrm{H}, J=7.5 \mathrm{~Hz}, 0.9 \mathrm{~Hz}), 6.63(\mathrm{t}, 1 \mathrm{H}, J=7.5 \mathrm{~Hz}), 4.14,4.06$ $(\mathrm{AB}, 2 \mathrm{H}, J=10.8 \mathrm{~Hz}), 3.32(\mathrm{~d}, 1 \mathrm{H}, J=8.7 \mathrm{~Hz}), 3.10-3.02(\mathrm{~m}, 1 \mathrm{H}), 2.93(\mathrm{~d}, 1 \mathrm{H}, J=8.7 \mathrm{~Hz})$, 2.87 (ddd, $1 \mathrm{H}, J=10.5 \mathrm{~Hz}, 7.2 \mathrm{~Hz}, 4.8 \mathrm{~Hz}$ ), 2.68 (appt t, $2 \mathrm{H}, J=6.6 \mathrm{~Hz}$ ), 2.12-2.03 (m, $2 \mathrm{H}$ ), $2.08(\mathrm{~s}, 3 \mathrm{H}), 1.36(\mathrm{~s}, 3 \mathrm{H}) ;{ }^{13} \mathrm{C}$ NMR $\delta 171.4,149.5,132.5,127.4,120.7,119.9,118.8,69.3$, 64.7, 46.9, 44.9, 24.0, 23.1, 22.0, 21.1; MS (EI) m/z 245 (M+, 40), 172 (100), 170 (28), 144 (47); HRMS (EI) $m / z$ calcd for $\mathrm{C}_{15} \mathrm{H}_{19} \mathrm{NO}_{2} 245.1416$, found 245.1416 .

1-(2-Methylallyl)-1H-indole. ${ }^{23}$ According to a modified literature procedure, a solution of 803 $\mathrm{mg}(6.85 \mathrm{mmol})$ of indole (20) in $13 \mathrm{~mL}$ of DMF and $499 \mathrm{mg}(8.90 \mathrm{mmol})$ of powdered $\mathrm{KOH}$ was stirred at $60{ }^{\circ} \mathrm{C}$ for $10 \mathrm{~min}$, cooled to rt, and treated with $1.0 \mathrm{~mL}$ (10.2 mmol) of 3-bromo-2methylpropene. The reaction mixture was stirred at $60{ }^{\circ} \mathrm{C}$ for $18 \mathrm{~h}$, poured onto ice and diluted with $15 \mathrm{~mL}$ of EtOAc. The combined organic layers were washed with $\mathrm{H}_{2} \mathrm{O}$, brine, dried $\left(\mathrm{MgSO}_{4}\right)$, concentrated in vacuo and purified by chromatography on $\mathrm{SiO}_{2}$ (hexane) to afford 832 mg (4.85 mmol, 71\%) of 1-(2-methylallyl)- $H$-indole as a light green oil: IR (neat) 3054, 2913, 1657, 1612, 1462, 1333, 900, $739 \mathrm{~cm}^{-1} ;{ }^{1} \mathrm{H} \operatorname{NMR} \delta 7.61(\mathrm{~d}, 1 \mathrm{H}, J=7.8 \mathrm{~Hz}), 7.27(\mathrm{~d}, 1 \mathrm{H}, J=$ $8.1 \mathrm{~Hz}), 7.19-7.05(\mathrm{~m}, 2 \mathrm{H}), 7.02(\mathrm{~d}, 1 \mathrm{H}, J=3.3 \mathrm{~Hz}), 6.49(\mathrm{~d}, 1 \mathrm{H}, J=3.3 \mathrm{~Hz}), 4.86(\mathrm{~s}, 1 \mathrm{H})$, $4.68(\mathrm{~s}, 1 \mathrm{H}), 4.57$ (s, $2 \mathrm{H}), 1.62(\mathrm{~s}, 3 \mathrm{H}) ;{ }^{13} \mathrm{C}$ NMR $\delta 141.4,136.5,128.8,128.4,121.7,121.1$, 119.6, 112.8, 109.9, 101.5, 52.7, 20.0; MS (EI) $m / z 171\left(\mathrm{M}^{+}, 88\right), 156$ (70), 130 (100); HRMS (EI) $m / z$ calcd for $\mathrm{C}_{12} \mathrm{H}_{13} \mathrm{~N} 171.1048$, found 171.1046 . 
3-Bromo-1-((2-methyloxiran-2-yl)methyl)-1H-indole (21). To a solution of $746 \mathrm{mg}$ (4.35 mmol) of 1-(2-methylallyl)- $1 H$-indole in $43 \mathrm{~mL}$ of acetonitrile was added $814 \mathrm{mg}$ (4.57 mmol) of NBS. The reaction mixture was stirred overnight, quenched with $\mathrm{H}_{2} \mathrm{O}$ and extracted with $3 \mathrm{x}$ $10 \mathrm{~mL}$ of $\mathrm{Et}_{2} \mathrm{O}$. The combined organic layers were dried $\left(\mathrm{MgSO}_{4}\right)$ and concentrated in vacuo. According to General Protocol B, the crude oil, $765 \mathrm{mg}(6.53 \mathrm{mmol})$ of NMO and $395 \mu \mathrm{L}$ of $\mathrm{OsO}_{4}(3 \mathrm{~mol} \%, 0.33 \mathrm{M}$ in toluene) were reacted and the disappearance of starting material was monitored by TLC (hexanes:EtOAc; 2:1). The resulting golden oil was dissolved in $40 \mathrm{~mL}$ of THF and cooled to $0{ }^{\circ} \mathrm{C}$. The solution was treated with $1.04 \mathrm{~g}(26.1 \mathrm{mmol})$ of $\mathrm{NaH}(60 \%$ dispersion in mineral oil) and stirred for $15 \mathrm{~min}$. Upon addition of $1.70 \mathrm{~g}(5.22 \mathrm{mmol})$ of $p$ - $\mathrm{Ts}_{2} \mathrm{O}$, the disappearance of starting material was monitored by TLC (hexanes:EtOAc;, 2:1). After 35 min, the reaction was quenched with $\mathrm{H}_{2} \mathrm{O}$ and extracted with 3 × $15 \mathrm{~mL}$ of $\mathrm{Et}_{2} \mathrm{O}$. The combined organic layers were dried $\left(\mathrm{MgSO}_{4}\right)$ and concentrated in vacuo. The residue was purified by chromatography on $\mathrm{SiO}_{2}$ (hexanes:EtOAc; 6:1) to afford $947 \mathrm{mg}$ (3.55 mmol, 82\%, 3 steps) of 21 as an oil: IR (neat) 3117, 3051, 2985, 2928, 1612, 1457, 1322, $1012 \mathrm{~cm}^{-1} ;{ }^{1} \mathrm{H}$ NMR $\delta 7.56$ (d, $1 \mathrm{H}, J=8.1 \mathrm{~Hz}), 7.36(\mathrm{~d}, 1 \mathrm{H}, J=7.8 \mathrm{~Hz}), 7.30-7.16(\mathrm{~m}, 2 \mathrm{H}), 7.15(\mathrm{~s}, 1 \mathrm{H}), 4.30,4.09$ (AB, 2 $\mathrm{H}, J=15.0 \mathrm{~Hz}), 2.65,2.55(\mathrm{AB}, 2 \mathrm{H}, J=4.5 \mathrm{~Hz}), 1.26(\mathrm{~s}, 3 \mathrm{H}) ;{ }^{13} \mathrm{C} \mathrm{NMR} \delta 136.4,127.6,127.5$, 123.2, 120.6, 119.6, 110.0, 90.8, 56.4, 52.1, 51.6, 19.0; MS (EI) $m / z 265\left(\mathrm{M}^{+}, 50\right), 208$ (67), 186 (24), 129 (39), 69 (100); HRMS (EI) $m / z$ calcd for $\mathrm{C}_{12} \mathrm{H}_{12} \mathrm{NOBr} 265.0102$, found 265.0103.

Benzyl 2-methylcyclohex-2-enyl(phenyl)carbamate (23). To a solution of $224 \mathrm{mg}(2.00 \mathrm{mmol})$ of 2-methylcyclohex-2-enol in $5 \mathrm{~mL}$ of dichloromethane cooled to $0{ }^{\circ} \mathrm{C}$ was added $840 \mu \mathrm{L}(6.03$ mmol) of $\mathrm{NEt}_{3}$ followed by $310 \mu \mathrm{L}(4.01 \mathrm{mmol})$ of $\mathrm{MsCl}$. Upon addition, the mixture was allowed to warm slowly to $25{ }^{\circ} \mathrm{C}$ overnight. The solution was quenched with $10 \mathrm{~mL}$ of $\mathrm{H}_{2} \mathrm{O}$, extracted with $3 \times 5 \mathrm{~mL}$ of dichloromethane, dried $\left(\mathrm{Na}_{2} \mathrm{SO}_{4}\right)$, concentrated, and used without further purification. To a solution of $396 \mathrm{mg}(2.40 \mathrm{mmol})$ of benzyl phenylcarbamate in $10 \mathrm{~mL}$ of dry DMF cooled to $0{ }^{\circ} \mathrm{C}$ was added $120 \mathrm{mg}(3.00 \mathrm{mmol})$ of $\mathrm{NaH}(60 \%)$. The reaction mixture was stirred for $15 \mathrm{~min}$ at $0{ }^{\circ} \mathrm{C}$ and then the crude mesylate intermediate was added in $1 \mathrm{~mL}$ of dry DMF. The resulting yellow mixture was allowed to warm to $25{ }^{\circ} \mathrm{C}$ overnight, quenched with 10 $\mathrm{mL}$ of $\mathrm{H}_{2} \mathrm{O}$, extracted with $3 \times 10 \mathrm{~mL}$ of EtOAc, washed with $10 \mathrm{~mL}$ of water and $10 \mathrm{~mL}$ of brine, dried $\left(\mathrm{Na}_{2} \mathrm{SO}_{4}\right)$, and concentrated. The residue was purified by chromatography on $\mathrm{SiO}_{2}$ (hexanes:Et $\left.\mathrm{O}_{2} ; 10: 1\right)$ to afford $361 \mathrm{mg}(1.12 \mathrm{mmol}, 56 \%, 2$ steps) of 23 as a light yellow oil. IR (ATR) 3032, 1697, 1597, 1495, 1453, 1396, 1293, 1120, $1017 \mathrm{~cm}^{-1}$; ${ }^{1} \mathrm{H}$ NMR $(300 \mathrm{MHz}, 350 \mathrm{~K}$, DMSO- $\left.d_{6}\right) \delta$ 7.39-7.22 (m, $\left.8 \mathrm{H}\right), 7.17-7.14(\mathrm{~m}, 2 \mathrm{H}), 5.57$ (bs, $\left.1 \mathrm{H}\right), 5.11,5.06(\mathrm{AB}, 2 \mathrm{H}, J=$ $12.9 \mathrm{~Hz}), 4.68$ (app t, $1 \mathrm{H}, J=7.2 \mathrm{~Hz}), 1.91-1.64(\mathrm{~m}, 4 \mathrm{H}), 1.76(\mathrm{~s}, 3 \mathrm{H}), 1.47-1.24(\mathrm{~m}, 2 \mathrm{H}) ;{ }^{13} \mathrm{C}$ NMR $\left(75 \mathrm{MHz}, 350 \mathrm{~K}\right.$, DMSO- $\left.d_{6}\right) \delta 154.4,140.1,136.4,133.0,128.1,127.7,127.1,126.7$, $126.3,125.6,65.9,57.2,27.4,24.0,19.9,19.8$; MS (ESI) $m / z 322\left([\mathrm{M}+\mathrm{H}]^{+}\right)$.

(4aS,9aS)-Benzyl 4a-methyl-4-oxo-2,3,4,4a-tetrahydro-1 $\mathrm{H}$-carbazole-9(9aH)-carboxylate (26). To a solution of $952 \mathrm{mg}(2.96 \mathrm{mmol})$ of $\mathbf{2 3}$ in $12 \mathrm{~mL}$ of dichloromethane and $691 \mathrm{mg}$ (6.52 mmol) of $\mathrm{Na}_{2} \mathrm{CO}_{3}$ (dissolved in $12 \mathrm{~mL}$ of water) at $0{ }^{\circ} \mathrm{C}$ was added $1.46 \mathrm{~g}(5.92 \mathrm{mmol})$ of $\mathrm{m}$ CPBA (70\%). Upon addition of the oxidant, the mixture was allowed to warm slowly to $25{ }^{\circ} \mathrm{C}$. After $2 \mathrm{~h}$, the reaction was quenched with $10 \mathrm{~mL}$ of a $1 \mathrm{M} \mathrm{Na}_{2} \mathrm{~S}_{2} \mathrm{O}_{3}$ solution, diluted with $5 \mathrm{~mL}$ 
of $\mathrm{H}_{2} \mathrm{O}$, extracted with $3 \times 10 \mathrm{~mL}$ of dichloromethane, washed with $10 \mathrm{~mL}$ of brine, dried $\left(\mathrm{MgSO}_{4}\right)$, concentrated, and purified by chromatography on $\mathrm{SiO}_{2}$ (hexanes:EtOAc; 10:1 with 1\% $\mathrm{NEt}_{3}$ to hexanes:EtOAc; 5:1 gradient) to afford $841 \mathrm{mg}(2.49 \mathrm{mmol}, 84 \%)$ of 24 as a colorless oil.

A mixture of $841 \mathrm{mg}(2.49 \mathrm{mmol})$ of $\mathbf{2 4}, 18.9 \mathrm{mg}(0.0759 \mathrm{mmol})$ of $\mathrm{Cp}_{2} \mathrm{TiCl}_{2}, 589 \mathrm{mg}(3.73$ mmol) of Coll $\bullet \mathrm{HCl}$ and $274 \mathrm{mg}(4.99 \mathrm{mmol})$ of $\mathrm{Mn}$ powder was then purged 3 times with Ar, diluted with $24 \mathrm{~mL}$ of THF and placed in a pre-heated oil bath. After heating at reflux under Ar overnight, the solution was cooled to $25{ }^{\circ} \mathrm{C}$, quenched with $10 \mathrm{~mL}$ of satd. $\mathrm{NH}_{4} \mathrm{Cl}$, extracted with $3 \times 10 \mathrm{~mL}$ of EtOAc, washed with $10 \mathrm{~mL}$ of brine, dried $\left(\mathrm{Na}_{2} \mathrm{SO}_{4}\right)$, concentrated, and purified by chromatography on $\mathrm{SiO}_{2}$ (hexanes:EtOAc; 5:1 with 1\% $\mathrm{NEt}_{3}$ to hexanes:EtOAc; 1:1) to afford 97 $\mathrm{mg}(0.29 \mathrm{mmol}, 12 \%)$ of $\mathbf{2 5}$ as a light brown oil that was taken on to the Dess-Martin oxidation. To a solution of $97 \mathrm{mg}(0.29 \mathrm{mmol})$ of the alcohol intermediate in $5 \mathrm{~mL}$ of dichloromethane was added $366 \mathrm{mg}$ ( $0.862 \mathrm{mmol})$ of Dess-Martin periodinane reagent. This mixture was stirred under $\mathrm{N}_{2}$ at $25{ }^{\circ} \mathrm{C}$ overnight and after $13 \mathrm{~h}$ reaction time, TLC analysis (hexanes:EtOAc;4:1) showed that the starting material had been consumed. The mixture was poured over $10 \mathrm{~mL}$ of satd. $\mathrm{NaHCO}_{3}$, partitioned, and extracted with $3 \times 5 \mathrm{~mL}$ of dichloromethane. The combined organic layers were dried $\left(\mathrm{Na}_{2} \mathrm{SO}_{4}\right)$, concentrated, and purified by chromatography on $\mathrm{SiO}_{2}$ (hexanes:EtOAc; $6: 1)$ to afford $61 \mathrm{mg}(0.18 \mathrm{mmol}, 63 \%, 6 \%$ over 3 steps) of $\mathbf{2 6}$ as a colorless oil: IR (ATR) 2957, 1700, 1597, 1479, 1401, 1287, $1084 \mathrm{~cm}^{-1}$; ${ }^{1} \mathrm{H}$ NMR (365 K, DMSO- $\left.d_{6}\right) \delta 7.71$ $(\mathrm{d}, 1 \mathrm{H}, J=8.1 \mathrm{~Hz}), 7.48-7.33(\mathrm{~m}, 5 \mathrm{H}), 7.28-7.19(\mathrm{~m}, 1 \mathrm{H}), 7.04-6.96(\mathrm{~m}, 2 \mathrm{H})$, 5.36-5.29 (m, 2 H), 4.47-4.43 (m, 1 H), 2.44-2.20 (m, $2 \mathrm{H}), 2.13-2.00$ (m, $1 \mathrm{H}), 1.80-1.64$ (m, $3 \mathrm{H}), 1.33$ (s, $3 \mathrm{H})$; ${ }^{13} \mathrm{C}$ NMR $\left(365 \mathrm{~K}\right.$, DMSO- $\left.d_{6}\right) \delta 207.8,151.5,140.4,135.8,133.5,127.9,127.8,127.3,127.1$, 122.6, 122.5, 114.4, 68.0, 66.3, 55.1, 37.1, 27.2, 24.5, 17.3; HRMS (TOF MS ES ${ }^{+}$) $m / z$ calcd for $\mathrm{C}_{21} \mathrm{H}_{21} \mathrm{NO}_{3} 358.1419$, found 358.1443.

Methyl 2,6-dichloroisonicotinate. According to a literature procedure, ${ }^{24}$ a flask was charged with $9.57 \mathrm{~g}(61.71 \mathrm{mmol})$ of citrazinic acid, $7.44 \mathrm{~g}(67.88 \mathrm{mmol})$ of $\mathrm{Me}_{4} \mathrm{NCl}$, and $17 \mathrm{~mL}(188.2$ mmol) of $\mathrm{POCl}_{3}$. The reaction mixture was heated to $130{ }^{\circ} \mathrm{C}$ for $18 \mathrm{~h}$, cooled to $0{ }^{\circ} \mathrm{C}$ and quenched with $200 \mathrm{~mL}$ of freshly distilled $\mathrm{MeOH}$. The solution was neutralized with powdered $\mathrm{NaHCO}_{3}$, diluted with $200 \mathrm{~mL}$ of $\mathrm{H}_{2} \mathrm{O}$ and concentrated in vacuo. The residue was extracted with $2 \times 150 \mathrm{~mL}$ of toluene, dried $\left(\mathrm{MgSO}_{4}\right)$, concentrated and filtered through a plug of $\mathrm{SiO}_{2}$

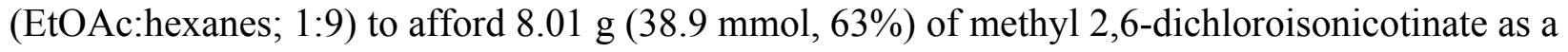
pink solid that was used without further purification: Mp 80-81 ${ }^{\circ} \mathrm{C} ;{ }^{1} \mathrm{H}$ NMR $\delta 7.82(\mathrm{~s}, 2 \mathrm{H}), 3.98$ (s, $3 \mathrm{H})$; MS (EI) $m / z 205\left(\mathrm{M}^{+}, 54\right), 174$ (100), 146 (53).

2,6-Dichloroisonicotinic acid (27). According to a literature procedure, ${ }^{24}$ a solution of $8.91 \mathrm{~g}$ (43.24 mmol) of methyl 2,6-dichloroisonicotinate in $20 \mathrm{~mL}$ of THF was treated with $1.24 \mathrm{~g}$ $(51.89 \mathrm{mmol})$ of $\mathrm{LiOH}$ in $60 \mathrm{~mL}$ of $\mathrm{H}_{2} \mathrm{O}$. The reaction mixture was stirred for $20 \mathrm{~min}$ at $\mathrm{rt}$ and concentrated in vacuo to remove the THF. The resulting solution was cooled to $0{ }^{\circ} \mathrm{C}$ and treated with $25 \mathrm{~mL}$ of $2 \mathrm{M} \mathrm{HCl}$ solution. After $2 \mathrm{~h}$, the solid was filtered and dried to afford $6.05 \mathrm{~g} \mathrm{(31.5}$ mmol, 73\%) of 27 as a tan solid: Mp 208-210 ${ }^{\circ} \mathrm{C} ;{ }^{1} \mathrm{H}$ NMR $\delta 7.86$ (s, $\left.2 \mathrm{H}\right)$; MS (EI) $m / z 191\left(\mathrm{M}^{+}\right.$, 100), 174 (61), 156 (43), 85 (56). 
Benzyl 2,6-dichloropyridin-4-ylcarbamate (28). ${ }^{24}$ To a solution of $1.00 \mathrm{~g}(5.20 \mathrm{mmol})$ of $27 \mathrm{in}$ $20 \mathrm{~mL}$ of THF was added $540 \mu \mathrm{L}(6.35 \mathrm{mmol})$ of oxalyl chloride at rt. The reaction mixture was refluxed for $2 \mathrm{~h}$, cooled to $\mathrm{rt}$ and concentrated in vacuo. The resulting oil was dissolved in $40 \mathrm{~mL}$ of freshly distilled acetone, cooled to $0{ }^{\circ} \mathrm{C}$ and treated dropwise with a solution of $1.01 \mathrm{~g}$ (15.62 mmol) of $\mathrm{NaN}_{3}$ in $20 \mathrm{~mL}$ of $\mathrm{H}_{2} \mathrm{O}$. The mixture was stirred for $90 \mathrm{~min}$, and the temperature was allowed to increase from $0{ }^{\circ} \mathrm{C}$ to $10{ }^{\circ} \mathrm{C}$. The mixture was diluted with $15 \mathrm{~mL}$ of distilled $\mathrm{Et}_{2} \mathrm{O}$, and the aqueous layer was extracted with $2 \times 10 \mathrm{~mL}$ of distilled $\mathrm{Et}_{2} \mathrm{O}$. The combined organic layers were dried $\left(\mathrm{MgSO}_{4}\right)$ and concentrated to $\sim 10 \%$ volume. After addition of $10 \mathrm{~mL}$ of toluene the remaining $\mathrm{Et}_{2} \mathrm{O}$ and acetone were removed under reduced pressure. The residue was dissolved in $15 \mathrm{~mL}$ of toluene, stirred with $\mathrm{MgSO}_{4}$ and treated with $1.1 \mathrm{~mL}$ (10.41 mmol) of benzyl alcohol. The mixture was heated at reflux for $15 \mathrm{~h}$ behind a blast shield, cooled to $\mathrm{rt}$, diluted with water and extracted with $2 \times 10 \mathrm{~mL}$ of EtOAc. The combined organic layers were dried $\left(\mathrm{MgSO}_{4}\right)$, concentrated and purified on $\mathrm{SiO}_{2}$ (hexanes:EtOAc; 20:1 to 10:1 gradient) to afford $580 \mathrm{mg}$ (1.95 mmol, 33\%, 3 steps) of 28 as a brown oil: IR (ATR) 3302, 3259, 3153, 1699, 1572, 1505, 1250, 1218, $1071 \mathrm{~cm}^{-1} ;{ }^{1} \mathrm{H}$ NMR $\delta 7.37$ (bs, $\left.5 \mathrm{H}\right), 7.36(\mathrm{~s}, 2 \mathrm{H}), 5.21(\mathrm{~s}, 2 \mathrm{H})$; ${ }^{13} \mathrm{C}$ NMR $\delta 152.4,151.4,149.1,135.1,129.0,128.9,128.7,111.4,68.3$; MS (EI) $m / z 296\left(\mathrm{M}^{+}\right.$, 37), 278 (82), 261 (61), 91 (100); HRMS (EI) $m / z$ calcd for $\mathrm{C}_{13} \mathrm{H}_{10} \mathrm{Cl}_{2} \mathrm{~N}_{2} \mathrm{O}_{2}$ 296.0119, found 296.0112.

Benzyl 2,6-dichloropyridin-4-yl(2-methylallyl) carbamate. A solution of $547 \mathrm{mg}(1.84 \mathrm{mmol})$ of 28 in $10 \mathrm{~mL}$ of THF at $0{ }^{\circ} \mathrm{C}$ was treated with $34 \mathrm{mg}(0.09 \mathrm{mmol})$ of TBAI and $93 \mathrm{mg}(3.68$ $\mathrm{mmol})$ of $\mathrm{NaH}(95 \%)$. The reaction mixture was stirred for $5 \mathrm{~min}$, treated with $370 \mu \mathrm{L}(3.68$ $\mathrm{mmol}$ ) of 3-bromo-2-methylpropene, warmed to $\mathrm{rt}$ and stirred for $16 \mathrm{~h}$. After addition of $160 \mathrm{mg}$ of $\mathrm{NaH}$ and $400 \mu \mathrm{L}$ of 3-bromo-2-methylpropene, the mixture was stirred until starting material was consumed according to TLC (hexanes:EtOAc; $4: 1$ ). The solution was then cooled to $0{ }^{\circ} \mathrm{C}$, quenched with water and extracted with $3 \times 10 \mathrm{~mL}^{\text {of }} \mathrm{Et}_{2} \mathrm{O}$. The combined organic layers were dried $\left(\mathrm{MgSO}_{4}\right)$, concentrated in vacuo and purified on $\mathrm{SiO}_{2}$ (hexanes:EtOAc; 15:1 to 10:1 gradient) to afford $497 \mathrm{mg}(1.41 \mathrm{mmol}, 77 \%)$ of benzyl 2,6-dichloropyridin-4-yl(2methylallyl)carbamate as a colorless oil: IR (ATR) 3280, 1716, 1576, 1367, 1216, $1159 \mathrm{~cm}^{-1} ;{ }^{1} \mathrm{H}$ NMR $\delta$ 7.38-7.36 (m, 5 H), $7.30(\mathrm{~s}, 2 \mathrm{H}), 5.25(\mathrm{~s}, 2 \mathrm{H}), 4.94(\mathrm{~s}, 1 \mathrm{H}), 4.74(\mathrm{~s}, 1 \mathrm{H}), 4.26(\mathrm{~s}, 2 \mathrm{H})$, $1.74(\mathrm{~s}, 3 \mathrm{H}) ;{ }^{13} \mathrm{C}$ NMR $\delta$ 154.0, 153.4, 151.0, 139.6, 135.4, 128.9, 128.8, 128.4, 116.2, 111.8 , 69.0, 54.4, 20.2; MS (EI) $\mathrm{m} / z 350\left(\mathrm{M}^{+}, 38\right), 259$ (30), 215 (80), 91 (100); HRMS (EI) $\mathrm{m} / z$ calcd for $\mathrm{C}_{17} \mathrm{H}_{16} \mathrm{Cl}_{2} \mathrm{~N}_{2} \mathrm{O}_{2} 350.0588$, found 350.0571 .

Benzyl 2,6-dichloropyridin-4-yl((2-methyloxiran-2-yl)methyl)carbamate (29). To a solution of $429 \mathrm{mg}$ (1.22 mmol) of benzyl 2,6-dichloropyridin-4-yl(2-methylallyl)carbamate in $10 \mathrm{~mL}$ of dichloromethane at $0{ }^{\circ} \mathrm{C}$ was added $451 \mathrm{mg}(1.83 \mathrm{mmol})$ of $m$-CPBA $(70 \%)$. The reaction mixture was warmed to $\mathrm{rt}$ and after $6 \mathrm{~h}$ an additional 1 equiv (300 $\mathrm{mg}$ ) of $m$-CPBA was added. The mixture was stirred for a total of $11 \mathrm{~h}$, cooled to $0{ }^{\circ} \mathrm{C}$, quenched with aq. $\mathrm{Na}_{2} \mathrm{~S}_{2} \mathrm{O}_{3}$ solution and extracted with $3 \times 10 \mathrm{~mL}$ of dichloromethane. The combined organic layers were dried $\left(\mathrm{MgSO}_{4}\right)$, concentrated and purified on $\mathrm{SiO}_{2}$ (hexanes:EtOAc; 8:1) to afford $371 \mathrm{mg}$ (1.01 mmol, $83 \%$ ) of 29 as a colorless oil: IR (ATR) 3089, 1714, 1576, 1535, 1216, 1149, $1088 \mathrm{~cm}^{-1} ;{ }^{1} \mathrm{H}$ 
NMR $\delta 7.39(\mathrm{~s}, 2 \mathrm{H}), 7.39-7.37(\mathrm{~m}, 5 \mathrm{H}), 5.28,5.21(\mathrm{AB}, 2 \mathrm{H}, J=12.0 \mathrm{~Hz}), 4.11,3.78(\mathrm{AB}, 2 \mathrm{H}$, $J=15.6 \mathrm{~Hz}), 2.60,2.58(\mathrm{AB}, 2 \mathrm{H}, J=4.2 \mathrm{~Hz}), 1.32(\mathrm{~s}, 3 \mathrm{H}) ;{ }^{13} \mathrm{C} \mathrm{NMR} \delta 154.1,153.6,151.0$, $135.1,129.0,129.0,128.7,117.8,69.1,56.1,53.3,51.7,19.5$; MS (ESI) $m / z 389[\mathrm{M}+\mathrm{Na}]^{+}$(14), 365 (22), 361 (100); HRMS (ESI) $\mathrm{m} / z$ calcd for $\mathrm{C}_{17} \mathrm{H}_{16} \mathrm{Cl}_{2} \mathrm{O}_{3} \mathrm{Na} 389.0436(\mathrm{M}+\mathrm{Na})$, found 389.0467.

Benzyl 4,6-dichloro-3-(hydroxymethyl)-3-methyl-2,3-dihydro-1H-pyrrolo[3,2-c]pyridine-1carboxylate. According to General Protocol F, $236 \mathrm{mg}(0.72 \mathrm{mmol})$ of 29, $7.1 \mathrm{mg}(0.02 \mathrm{mmol})$ of $\mathrm{Cp}_{2} \mathrm{TiCl}_{2}, 170 \mathrm{mg}(1.08 \mathrm{mmol})$ of collidine hydrochloride, and $59 \mathrm{mg}$ (1.08 mmol) of $\mathrm{Mn}$ powder (reaction time $2 \mathrm{~h}$ ) afforded an oil that was purified on $\mathrm{SiO}_{2}$ (toluene:acetone; 8:1) to afford $147 \mathrm{mg}(0.40 \mathrm{mmol}, 55 \%)$ of benzyl 4,6-dichloro-3-(hydroxymethyl)-3-methyl-2,3dihydro-1H-pyrrolo[3,2-c]pyridine-1-carboxylate as a waxy solid: IR (ATR) 3397, 2965, 2877 , 1718, 1582, 1449, 1380, $1312 \mathrm{~cm}^{-1} ;{ }^{1} \mathrm{H}$ NMR $\delta$ 7.42-7.37 (m, $\left.6 \mathrm{H}\right), 5.30-5.20(\mathrm{~m}, 2 \mathrm{H}), 4.31(\mathrm{~d}, 1$ $\mathrm{H}, J=11.1 \mathrm{~Hz}), 4.14(\mathrm{~d}, 1 \mathrm{H}, J=11.1 \mathrm{~Hz}), 3.74(\mathrm{~d}, 1 \mathrm{H}, J=11.1 \mathrm{~Hz}), 3.58(\mathrm{~d}, 1 \mathrm{H}, J=11.1 \mathrm{~Hz})$, 2.62 (bs, $1 \mathrm{H}), 1.41(\mathrm{~s}, 3 \mathrm{H}) ;{ }^{13} \mathrm{C}$ NMR $\delta 154.6,152.4,150.7,145.0,135.3,128.9,128.6,127.3$, 109.4, 68.5, 66.1, 59.1, 46.3 21.4; MS (EI) $m / z 368$ ([M+2] $\left.]^{+}, 9\right), 366\left(\mathrm{M}^{+}, 15\right), 201$ (10), 91 (100); HRMS (EI) $m / z$ calcd for $\mathrm{C}_{17} \mathrm{H}_{16} \mathrm{Cl}_{2} \mathrm{~N}_{2} \mathrm{O}_{3} 366.0538$, found 366.0527 .

(3-Methyl-2,3-dihydro-1H-pyrrolo[3,2-c]pyridin-3-yl)methanol (30). To a solution of $78 \mathrm{mg}$ (0.21 mmol) of benzyl 4,6-dichloro-3-(hydroxymethyl)-3-methyl-2,3-dihydro-1H-pyrrolo[3,2c]pyridine-1-carboxylate in $2 \mathrm{~mL}$ of $\mathrm{MeOH}$ at $\mathrm{rt}$ was added $22 \mathrm{mg}(0.02 \mathrm{mmol}) \mathrm{of} \mathrm{Pd} / \mathrm{C}$. The reaction mixture was saturated with 1 atm of $\mathrm{H}_{2}$, stirred for $21 \mathrm{~h}$, quenched with Celite ${ }^{\circledR}$, filtered, concentrated and purified on neutral $\mathrm{Al}_{2} \mathrm{O}_{3}$ (hexanes:EtOAc; $1: 1$ to $100 \% \mathrm{EtOH}$ ) to afford a white solid. This solid was washed once each $(5 \mathrm{~mL})$ with boiling acetone and boiling ethyl acetate. The organic extracts were combined and concentrated in vacuo to afford $33 \mathrm{mg}$ (0.20 mmol, 95\%) of $\mathbf{3 0}$ as a colorless oil: IR (ATR) 3248, 3160, 2925, 2866, 1649, 1608, 1522, $1030 \mathrm{~cm}^{-1} ;{ }^{1} \mathrm{H}$ NMR $\left(\mathrm{CD}_{3} \mathrm{OD}\right) \delta 7.94(\mathrm{~d}, 1 \mathrm{H}, J=6.3 \mathrm{~Hz}), 7.90(\mathrm{~s}, 1 \mathrm{H}) 6.61(\mathrm{~d}, 1 \mathrm{H}, J=6.3 \mathrm{~Hz})$, 3.77, $3.47(\mathrm{AB}, 2 \mathrm{H}, J=10.5 \mathrm{~Hz}), 3.60,3.53(\mathrm{AB}, 2 \mathrm{H}, J=10.8 \mathrm{~Hz}), 1.37(\mathrm{~s}, 3 \mathrm{H}) ;{ }^{13} \mathrm{C}$ NMR $\delta$ 162.2, 144.3, 137.1, 133.1, 103.9, 69.1, 58.1, 47.0, 23.6; MS (ESI) $m / z 165\left([\mathrm{M}+\mathrm{H}]^{+}, 100\right)$; HRMS (ESI) $m / z$ calcd for $\mathrm{C}_{9} \mathrm{H}_{12} \mathrm{~N}_{2} \mathrm{O}(\mathrm{M}+\mathrm{H}) 165.1028$, found 165.1038 . 


\section{References}

1. Ertl, P.; Jelfs, S.; Muehlbacher, J.; Schuffenhauer, A.; Selzer, P. J. Med. Chem. 2006, 49, 4568 .

2. (a) Anas, S.; Kagan, H. B. Tetrahedron: Asymmetry 2009, 20, 2193. (b) Humphrey, G. R.; Kuethe, J. T. Chem. Rev. 2006, 106, 2875. (c) Karp, G. M. Org. Prep. Proced. Int. 1993, 25, 481. (d) Pierce, J. G.; Waller, D. L.; Wipf, P. J. Organomet. Chem. 2007, 692, 4618. (e) Wang, C.; Widom, J.; Petronijevic, F.; Burnett, J. C.; Nuss, J. E.; Bavari, S.; Gussio, R.; Wipf, P. Heterocycles 2009, 79, 487. (f) Petronijevic, F.; Timmons, C.; Cuzzupe, A.; Wipf, P. Chem. Commun. 2009, 104. (g) Pierce, J. G.; Kasi, D.; Fushimi, M.; Cuzzupe, A.; Wipf, P. J. Org. Chem. 2008, 73, 7807. (h) Gribble, G. W. J. Chem. Soc. Perkin Trans. 1 2000, 1045. (i) Ersmark, K.; Del Valle, J. R.; Hanessian, S. Angew. Chem., Int. Ed. 2008, 47, 1202; and references cited therein.

3. (a) Song, J. J.; Reeves, J. T.; Gallou, F.; Tan, Z.; Yee, N. K.; Senanayake, C. H. Chem. Soc. Rev. 2007, 36, 1120. (b) Popowycz, F.; Merour, J.-Y.; Joseph, B. Tetrahedron 2007, 63, 8689.

4. (a) Nugent, W. A.; RajanBabu, T. V. J. Am. Chem. Soc. 1988, 110, 8561. (b) Rajanbabu, T. V.; Nugent, W. A. J. Am. Chem. Soc. 1994, 116, 986. (c) Gansäuer, A.; Bluhm, H.; Pierobon, M. J. Am. Chem. Soc. 1998, 120, 12849. (d) Gansäuer, A.; Pierobon, M.; Bluhm, H. Angew. Chem. Int. Ed. 1998, 37, 101. (e) Gansäuer, A.; Barchuk, A.; Keller, F.; Schmitt, M.; Grimme, S.; Gerenkamp, M.; Mück-Lichtenfeld, C.; Daasbjerg, K.; Svith, H. J. Am. Chem. Soc. 2007, 129, 1359, and references cited therein.

5. For reviews of Ti(III) chemistry, see: (a) Gansäuer, A.; Pierobon, M.; Bluhm, H. Synthesis 2001, 16, 2500. (b) Barrero, A. F.; Quilez del Moral, J. F.; Sanchez, E. M.; Arteaga, J. F. Eur. J. Org. Chem. 2006, 1627. For recent applications see: (c) Justicia, J.; Oller-Lopez, J. L.; Campana, A. G.; Oltra, J. E.; Cuerva, J. M.; Bunuel, E.; Cardenas, D. J. J. Am. Chem. Soc. 2005, 127, 14911-14921. (d) Fernandez-Mateos, A.; Herrero Teijon, P.; Mateos Buron, L.; Rabanedo Clemente, R.; Rubio Gonzalez, R. J. Org. Chem. 2007, 72, 9973. (e) Monleon, L. M.; Grande, M.; Anaya, J. Tetrahedron 2007, 63, 3017. (f) Friedrich, J.; Walczak, K.; Dolg, M.; Piestert, F.; Lauterbach, T.; Worgull, D.; Gansäuer, A. J. Am. Chem. Soc. 2008, 130, 1788. (g) Mandal, S. K.; Paira, M.; Roy, S. C. J. Org. Chem. 2008, 73, 3823. (h) Gansäuer, A.; Piestert, F.; Huth, I.; Lauterbach, T. Synthesis, 2008, 21, 3509. (i) Justicia, J.; Jimenez, T.; Morcillo, S. P.; Cuerva, J. M. Oltra, J. E. Tetrahedron 2009, 65, 10837. (j) Fernandez-Mateos, A.; Madrazo, S. E.; Teijon, P. H.; Gonzalez, R. R. J. Org. Chem. 2009, 74, 3913.

6. Wipf, P.; Maciejewski, J. P. Org. Lett. 2008, 10, 4383.

7. (a) Edwards, J. P.; West, S. J.; Pooley, C. L. F.; Marschke, K. B.; Farmer, L. J.; Jones, T. K. Bioorg. Med. Chem. Lett. 1998, 8, 745. (b) Rudolph, A.; Rackelmann, N.; Turcotte-Savard, M.-O.; Lautens, M. J. Org. Chem. 2009, 74, 289.

8. (a) Inanaga, J.; Ujikawa, O.; Yamaguchi, M. Tetrahedron Lett. 1991, 32, 1737. (b) Fujita, K.; Yorimitsu, H.; Oshima, K. Bull. Chem. Soc. Jpn., 2004, 77, 1727. (c) Yanada, R.; Obika, 
S.; Nishimori, N.; Yamauchi, M.; Takemoto, Y. Tetrahedron Lett. 2004, 45, 2331. (d) Affo, W.; Ohmiya, H.; Fujioka, T.; Ikeda, Y.; Nakamura, T.; Yorimitsu, H.; Oshima, K.; Imamura, Y.; Mizuta, T.; Miyoshi, K. J. Am. Chem. Soc. 2006, 128, 8068. (e) Gauss, C. M.; Hamasaki, A.; Parrish, J. P.; MacMillan, K. S.; Rayl, T. J.; Hwang, I.; Boger, D. L. Tetrahedron 2009, 65, 6591.

9. Barrero, A. F.; Oltra, J. E.; Cuerva, J. M.; Rosales, A. J. Org. Chem. 2002, 67, 2566. (b) Justicia, J.; Rosales, A.; Bunuel, E.; Oller-Lopez, J. L.; Valdivia, M.; Haïdour, A.; Oltra, J. E.; Barrero, A. F.; Cardenas, D. J.; Cuerva, J. M. Chem. Eur. J. 2004, 10, 1778. (c) Cuerva, J. M.; Campana, A. G.; Justicia, J.; Rosales, A.; Oller-Lopez, J. L.; Robles, R.; Cardenas, D. J.; Bunuel, E.; Oltra, J. E. Angew. Chem. Int. Ed. 2006, 45, 5522.

10. Popowycz, F.; Merour, J.-Y.; Joseph, B. Tetrahedron 2007, 63, 8689. (b) Moustafa, M. M. A. R.; Pagenkopf, B. L. Org. Lett. 2010, 12, 3168.

11. For the application of a radical ipso substitution to azaindoline synthesis, see: Laot, Y.; Petit, L.; Zard, S. Z. Org. Lett. 2010, 12, 3426.

12. Scott, M. E.; Schwarz, C. A.; Lautens, M. Org. Lett. 2006, 8, 5521.

13. Bacque, E.; Qacemi, M. E.; Zard, S. Z. Org. Lett. 2004, 6, 3671.

14. Mello, J. V.; Finney, N. S. Org. Lett. 2001, 3, 4263.

15. (a) Curran, D.; Liu, H.; Josien, H.; Ko, S.-B. Tetrahedron 1996, 52, 11385. (b) Clyne, M. A.; Aldabbagh, F. Org. Biomol. Chem. 2006, 4, 268. (c) Clive, D. L. J.; Peng, J.; Fletcher, S. P.; Ziffle, V. E.; Wingert, D. J. Org. Chem. 2008, 73, 2330.

16. For oxidation processes during reductive cyclizations, see: (a) Bowman, W. R.; Heaney, H.; Jordan, B. M. Tetrahedron 1991, 47, 10119. (b) Beckwith, A. L. J.; Bowry, V. W.; Bowman, W. R.; Mann, E.; Parr, J.; Storey, J. M. D. Angew. Chem. Int. Ed. 2004, 43, 95. (c) Curran, D. P.; Keller, A. I. J. Am. Chem. Soc. 2006, 128, 13706.

17. For Friedel-Crafts cycloalkylations with aryl-alkyl oxiranes, see: (a) Taylor, S. K.; Hockerman, G. H.; Karrick, G. L.; Lyle, S. B.; Schramm, S. B. J. Org. Chem. 1983, 48, 2449. (b) Taylor, S. K.; May, S. A.; Stansby, E. S. J. Org. Chem. 1996, 61, 2075.

18. (a) Alcaide, B.; Almendros, P.; Alonso, J. M. Chem. Eur. J. 2003, 9, 5793. (b) MorenoManas, M.; Morral, L.; Pleixats, R. J. Org. Chem. 1998, 63, 6160.

19. Gingrich, D. E.; Yang, S. X.; Gessner, G. W.; Angeles, T. S.; Hudkins, R. L. J. Med.Chem. 2005, 48, 3776.

20. (a) Akbar, A.; Reddy, G. S. K. K.; Cao, H.; Anjum, S. G.; Nalam, M. N. L.; Schiffer, C. A.; Rana, T. M. J. Med. Chem. 2006, 49, 7342. (b) Pandey, R. K.; Dagade, S. P.; Dongare, M. K.; Kumar, P. Synth. Comm. 2003, 33, 4019.

21. Jacquemard, U.; Beneteau, V.; Lefoix, M.; Routier, S.; Merour, J.-Y.; Coudert, G. Tetrahedron 2004, 60, 10039.

22. Lebel, H.; Leogane, O. Org. Lett. 2006, 8, 5717.

23. Carreno, M. C.; Garcia Ruano, J. L.; Sanz, G.; Toledo, M. A.; Urbano, A. J. Org. Chem. 1995, 60, 5328.

24. Mello, J. V.; Finney, N. S. Org. Lett. 2001, 3, 4263. 